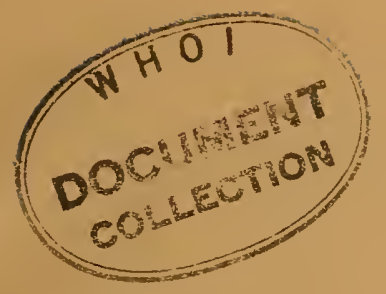

TECHNICAL REPORT

\title{
SUBMARINE GEOMORPHOLOGY OF EASTERN ROSS SEA AND SULZBERGER BAY, ANTARCTICA
}

\author{
Ocean Surveys Division \\ Author: Larry K. Lepley
}

JANUARY 1966

GC

1

.$T 43$

U. S. NAVAL OCEANOGRAPHIC OFFICE

No.TR -172

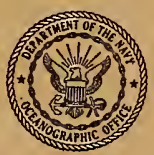
WASHINGTON, D.C. 20390

Price $\$ 1.00$ 


\section{A B STR A C T}

This report graphically describes the submarine topography of the eastern Ross Sea and Sulzberger Bay areas of Antarctica, and explains the origins of the bathymetric features.

The principal bathymetric data used were collected from the U.S. Navy's icebreaker STATEN ISLAND during the DEEP FREEZE 61 reconnaissance survey conducted in December 1960.

Recent marine sediments of the Antarctic continental shelf have been rafted from land by ice. A low rate of recent sedimentation on the continental shelf is especially evident at the inner shelf. The prevailing marine sediment of the area is glacial marine till. Hard sand surfaces occur where strong currents pass over transverse ridges near shore.

The outer shelf break averages about 255 fathoms in depth; the great depth of the outer shelf is attributed to remnant isostatic depression by the continental ice sheet of glacial maxima when the ice extended to the shelf break.

The great ( 600 fathoms) transverse depression of Sulzberger Bay may be the product of erosion during glacial maxima by a locally accelerated "ice stream" whose position was controlled by bedrock structure. The origin of the longitudinal depressions can be attributed to erosion by continental ice along zones of weakness due to lithologic changes or faulting parallel to the shoreline.

The longitudinal ridges are interpreted as end moraines formed during pauses in the retreat of the continental ice sheet. The transverse ridges are interpreted as lateral and end moraines of a former extension of the Ross Ice Sheet.

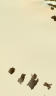




\section{FOREWORD}

This report describes and attempts to explain the origins of the submarine topography of an area in Antarctica surveyed during DEEP FREEZE 61 operations of Navy's icebreakers. The geomorphology of the continental shelf of Antarctica provides another key to the glacial history of that continent and its relation to the ice ages of the world.
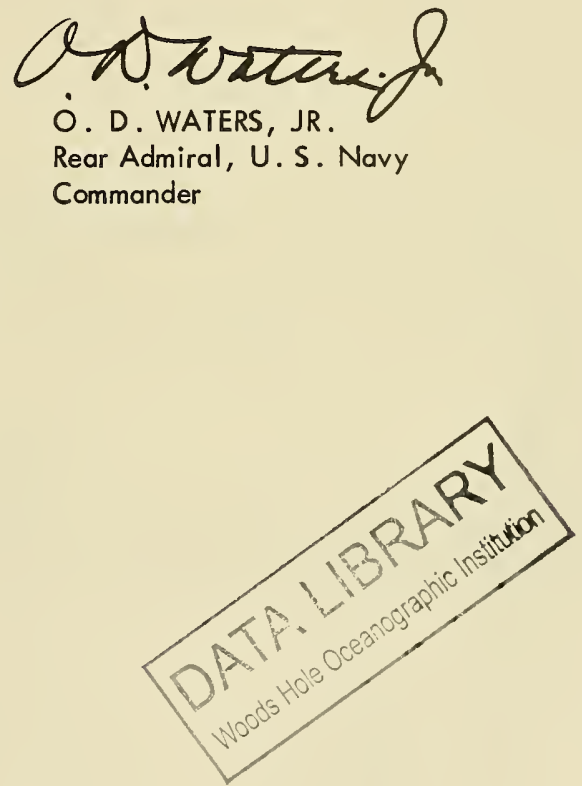


\section{INTRODUCTION}

A. Objectives of the Study ................. 1

B. Survey Techniques and Data Analysis . . . . . . . . . . . 1

II. BATHYMETRY OF EASTERN ROSS SEA AND SULZBERGER BAY . . 7
A. Outer Shelf ...................... 7
B. Inner Shelf ................... 7
C. Shelf Depressions .................. 7
D. Shelf Ridges ...................... 9

III. BOTTOM SEDIMENTS OF THE EASTERN ROSS SEA AND SULZBERGER BAY ........................ 10

A. Areal Geology and Glaciology ............... 11

B. Present Antarctic Marine Sediments . . . . . . . . . . 12

C. Present Glaciation. . . . . . . . . . . . . . 13

D. Prior Glaciation . . . . . . . . . . . . . . . . 14

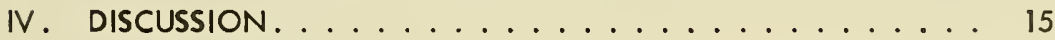

A. Outer Shelf ...................... 15

1. Eustatic, Isostatic, and Glacial History. ........ 15

2. Origin of the Outer Shelf - Summary and Conclusions. . . 19

B. Shelf Depressions and Inner Shelf . . . . . . . . . 20

1. Transverse Depression ................ . 21

2. Longitudinal Depressions and the Inner Shelf . . . . . . 22

C. Longitudinal Ridges . . . . . . . . . . . . . . . 24

D. Transverse Ridges . . . . . . . . . . . . . . 25

1. North-South Transverse Ridge . . . . . . . . . . . 26

2. East-West Transverse Ridge. . . . . . . . . . . . 28

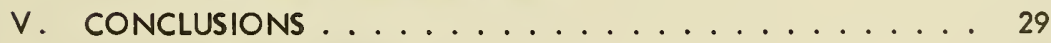

VI. ACKNOWLEDGMENTS ................. 30

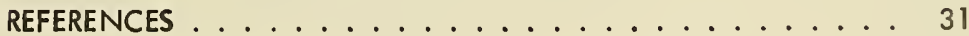




\section{FIGURES}

Figure 1. Survey Area Eastern Ross Sea and Sulzberger Bay,

Western Antarctica................. 2

Figure 2. Composite of Ship's Track, Station Locations, Profiles, Major Bathymetric Features, and Bottom Sediment Types, Eastern Ross Sea and Sulzberger Bay . . . . . . . . . . . . . 4

Figure 3. Bathymetric Profiles $A-B$ and $C-D \ldots \ldots \ldots$

Figure 4. Bathymetric Profiles E-F, G-H, and J-K . . . . 6

Figure 5. Eastern Ross Sea and Sulzberger Bay Bathymetry and Western Antarctica lce Cap Topography . . . . . . . . . . . . 8 


\section{INTRODUCTION}

A. Objectives of the Study

As a part of Operation Deep Freeze 61 (1960-1961), U.S. Naval Oceanographic Office personnel from aboard USS STATEN ISLAND (AGB-5) conducted a reconnaissance survey in the eastern Ross Sea and Sulzberger Bay, Antarctica, during December 1960. In addition to serial oceanographic station data, continuous sonic depth recordings were taken as the ship moved from station to station, and Phleger cores were obtained at 25 locations. Figure 1 shows the location of the survey area (latitudes $75^{\circ} 10^{\prime}$ to $78^{\circ} 48^{\prime} \mathrm{S}$ and longitudes $144^{\circ}$ to $164^{\circ} \mathrm{W}$ ). The National Science Foundation supported the scientific effort; bathymetric results are presented in the Report.

This study has two objectives: First, to construct a chart of the area describing the bathymetry and general sediment types of the eastern Ross Sea and Sulzberger Bay from survey data collected, from existing charts, and from reports of previous work published on the area. Second, to develop an explanation of the origin of these bathymetric features from bottom sediment samples collected and from the existing areal geological and glaciological literature published on the orea.

\section{B. Survey Techniques and Data Analysis}

Bathymetric data were collected along sounding lines that were approximately 30 miles apart, and serial oceanographic stations and Phleger cores were collected at approximately 30 -mile intervals along the sounding lines. The bathymetric data were recorded with an EDO AN/UQN-1B echo sounder, and sonic depth recordings representing 1,200 nautical miles of ship's tracks covering an area of 20,000 square miles were collected, processed, and analyzed. Serial oceanographic station data collected at 31 locations were processed, and these data are presented in Technical Report 105 "Operation Deep Freeze 61, 1960-1961, Marine Geophysical Investigations" June 1962, U.S. Novy Hydrographic Office. Also, included in Technical Report 105 are the locations and field descriptions of the 25 Phleger cores collected during the survey. All bottom samples obtained during the operation were shipped to the Department of Geology, Florida State University, Tallahassee,Florida for laboratory analysis and publication of the resulting data.

Navigational control was by dead reckoning, radar ranges and bearings on mountain peaks, and/or by sun-line fixes. Position errors were probably as great as 10 miles, possibly more. For example, (1) the degree of accuracy of the charted position of mountain peaks was uncertain, (2) the effects on the sun-line fixes of the refraction of the sun's rays resulting from the low angles of the sun above the horizon and the temperature inversions of the air layers were difficult to determine, and (3) straight courses could not be run owing to ice conditions. 


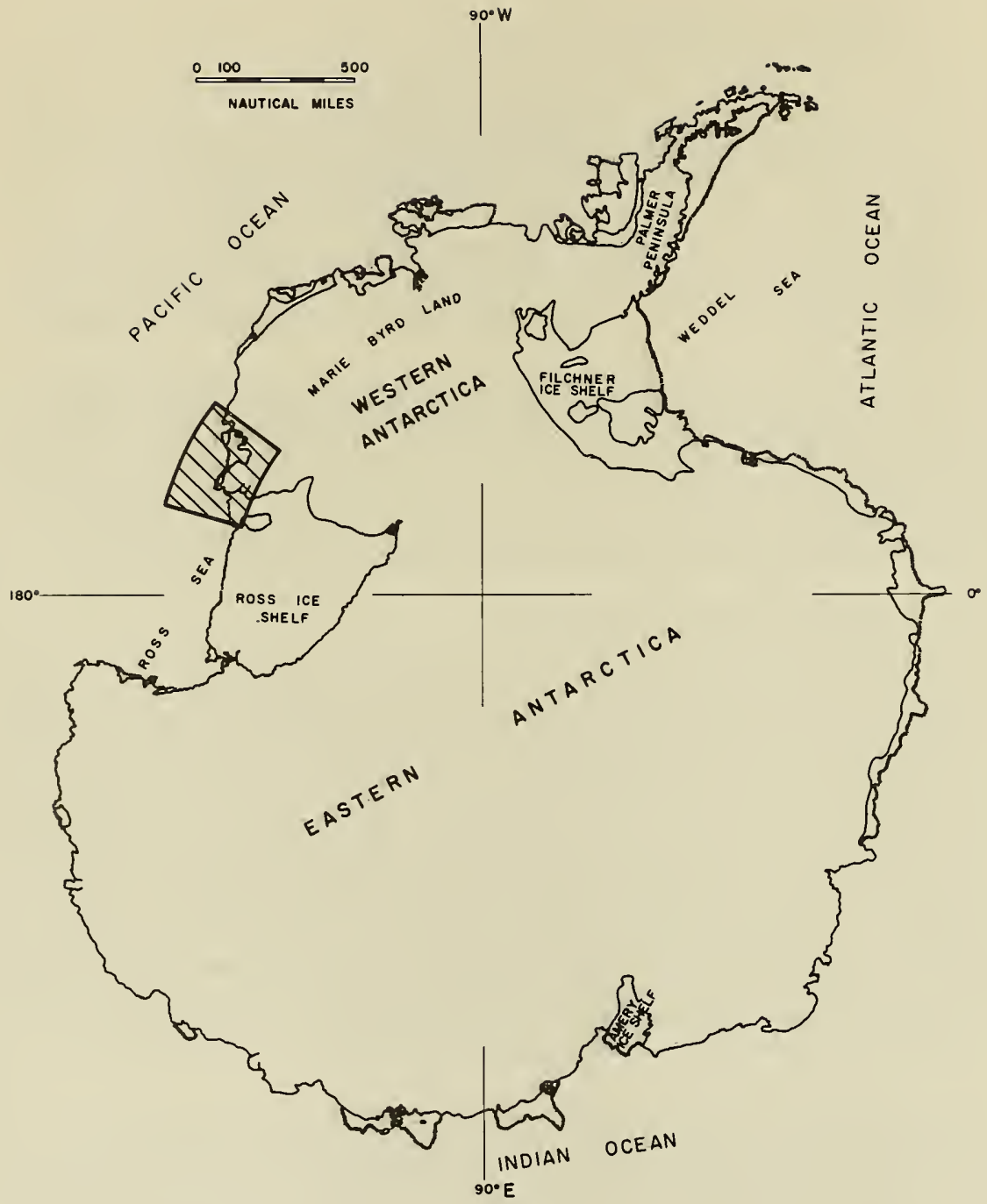

FIGURE 1. SURVEY AREA EASTERN ROSS SEA AND SULZBERGER BAY, WESTERN ANTARCTICA 
Profiles along the ship's tracks were constructed from the bathymetric data. The locations of these profiles are shown on Figure 2, and the profiles are presented as Figures 3 and 4 . The vertical exaggeration of the profiles is 20 to 1 , and the horizontal scale is 15 nautical miles per inch. Since the Edo EchoSounder is not a precision instrument, small bathymetric features (less than 10fathom relief or less than one percent of the depth) were Ignored, and no attempt was made to delineate microbathymetry. Corrections for positioning errors were made by adjusting the ship's tracks where the profiles intersected until depths agreed. Corrections were not made for ship's draft (4 l/2 fathoms) nor for the sound velocity of the water column (sound velocity was generally less than 4,800 feet per second, the calibration velocity of the echo sounder).

A chart describing the bothymetry of the eastern Ross Sea and Sulzberger Bay and the ice cap topography on the contiguous area of western Antarctica is presented as Figure 5. This chart was constructed from the USS STATEN ISLAND data, U. S. Navy H.O. Charts 6631 (1961 ed.) and 6637 (1961 ed.), and U.S. Air Force W.A. Chart 1823 (1953 ed.); supplemental bathymetric data collected by USS GLACIER (AGB-4) during Deep Freeze 62, and publications by Richard E. Byrd (1933) and S. E. Roos (1937) were also used in the preparation of this chart. The contours tracing the continental slope are dashed because of the paucity of soundings in that area, and the dashed 100-fathom closed contours northwest of Guest Island and Rupert Coast were bosed on the theory that chronically grounded icebergs mark the position of submerged ridges. 


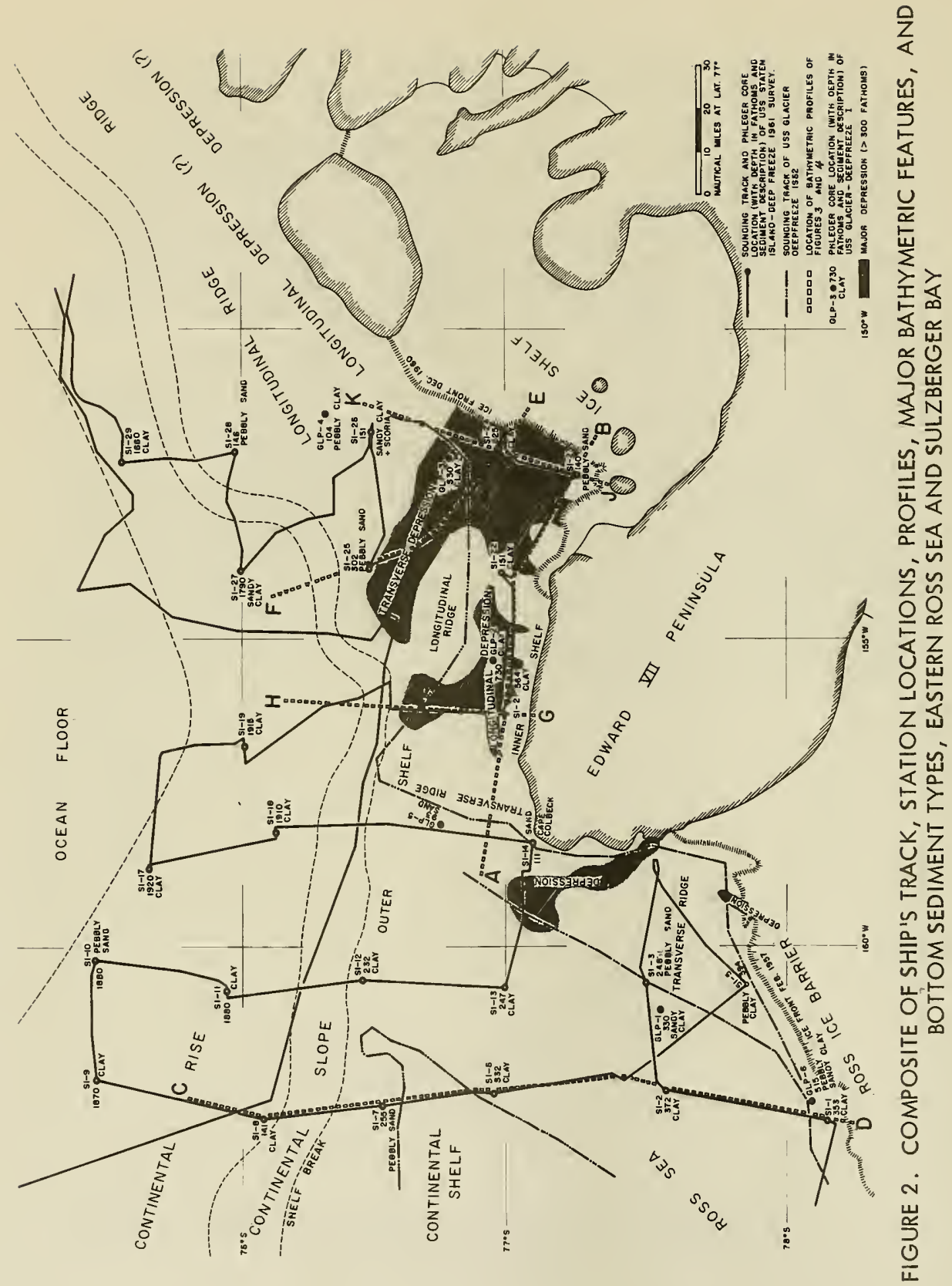



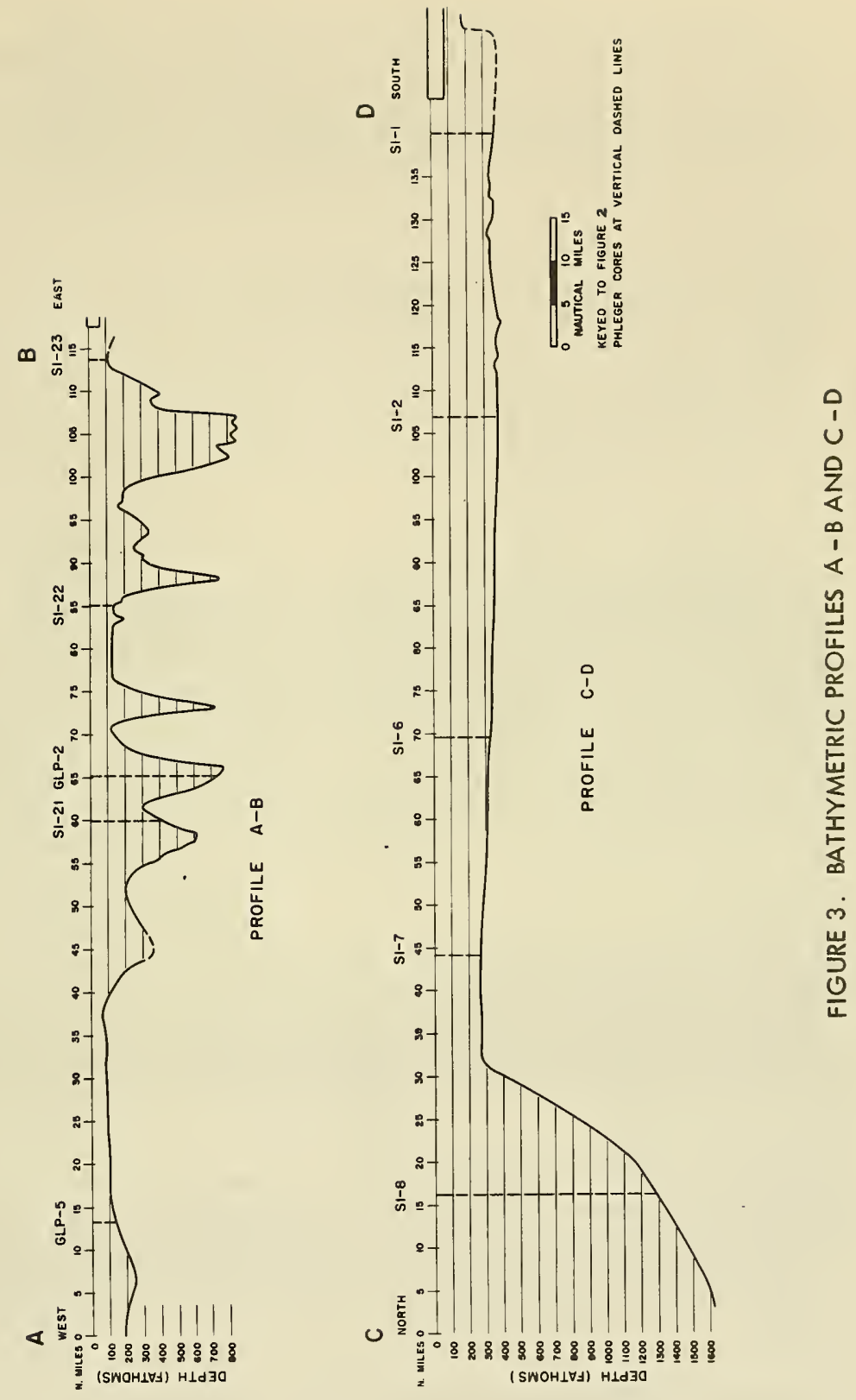
F

E

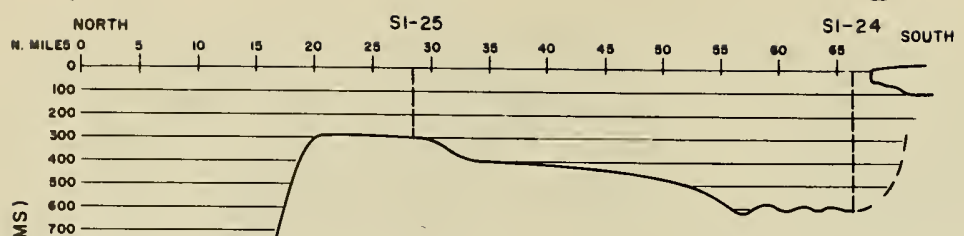

$$
\begin{aligned}
& \text { 농 }
\end{aligned}
$$

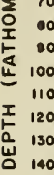

1500

1500

PROFILE E-F
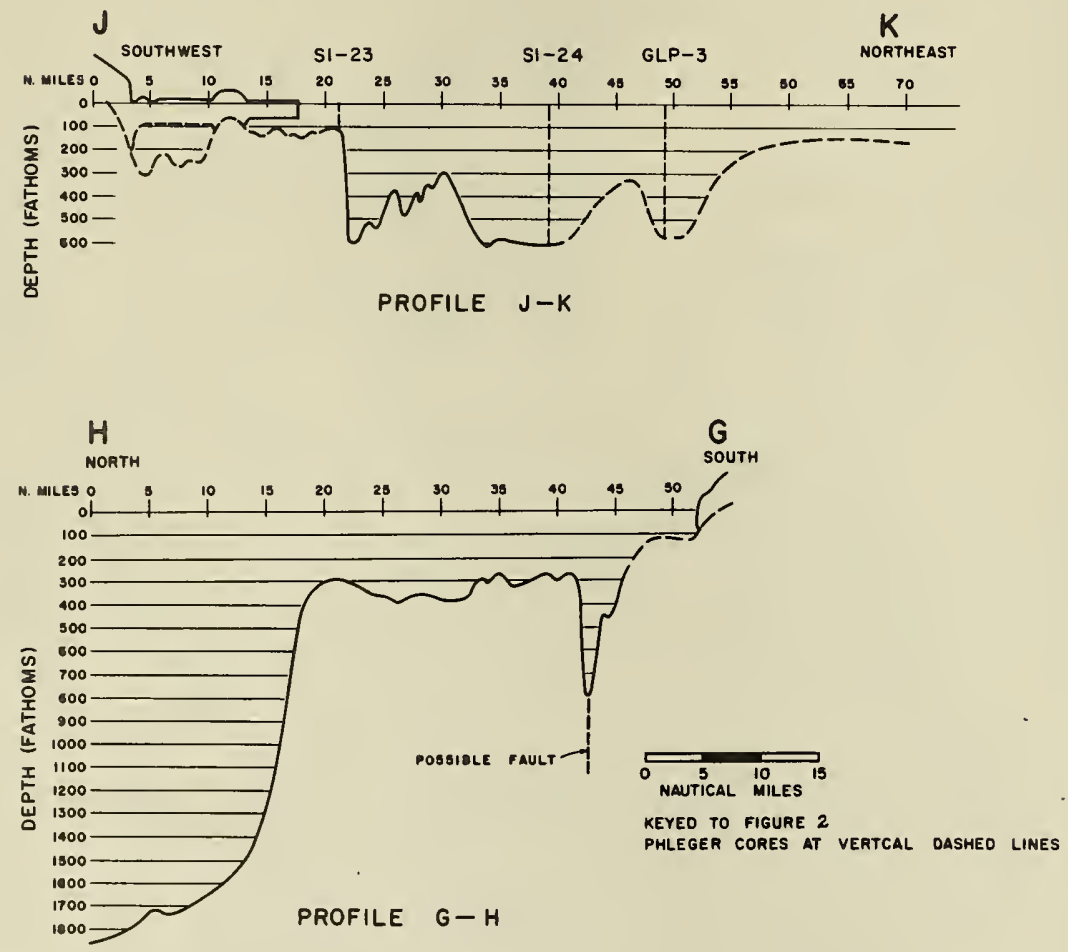

FIGURE 4. BATHYMETRIC PROFILES E -F, G-H, AND J-K 


\section{BATHYMETRY OF EASTERN ROSS SEA AND SULZBERGER BAY}

The morphological features of the eastern Ross Sea and Sulzberger Bay shown in Figures 2 through 5 can be classified as: (1) the outer shelf, (2) the inner shelf, (3) the shelf depressions, and (4) the shelf ridges.

\section{A. Outer Shelf}

The outer shelf (Fig. 2), the deep-lying terrace of the continental shelf, ends abruptly at between 210 and 280 fathoms below sea level where the steep (approximately 100 fathoms per mile) continental slope marks the beginning of the Pacific Antarctic Ocean. The outer shelf slopes gently toward land from the shelf edge, and the average depth of the flatter portions is about 300 fathoms . This inward tilt is especially evident in the Ross Sea where the shelf is relatively smooth (Profile C-D, Fig. 3).

\section{B. Inner Shelf}

The inner shelf (Fig. 2), so designated in text after Holtedahl (1958) who observed similar features, is a narrow, relatively shallow, hilly terrace that borders the shores of Edward VII Peninsula. The depths of this dissected terrace range from 115 to 200 fathoms. Across its flatter parts, its depth is 130 fathoms (Profile A-B, Fig. 3), and it is about 200 fathoms shallower than the flatter portions of the outer shelf (compare Profiles $A-B, C-D$, and $G-H$, Figs. 3 and 4). Off Cape Colbeck, the inner shelf narrows to one mile, but it broadens as it rounds the peninsula until it is 15 miles wide in Sulzberger Bay. The outer edge of this shelf is abruptly terminated by the shelf depressions.

\section{Shelf Depressions}

Shelf depressions (Fig. 2), great troughs within the continental shelf, are found close to shore. The depth Profile A-B (Fig. 3) shows a series of deep, steepwalled, fjord-like canyons cut into the inner shelf, and a 5-mile-wide canyon with a jagged floor at 730 to 860 fathoms. The slopes of the steep canyon walls appear to exceed $30^{\circ}$ in several places where the profiles show a vertical relief of up to 500 fathoms within one or two miles.

An east-west-trending canyon is shown on Profile G-H (Fig. 4). This narrow, 800-fathom canyon is bordered on its seaward side by the outer shelf and on its shore side by the inner shelf. This east-west depression, parallel to the north shore of Edward VII Peninsula, is referred to as the longitudinal depression after Holtedahl's (1958) description of similar depressions off other glaciated coasts. 


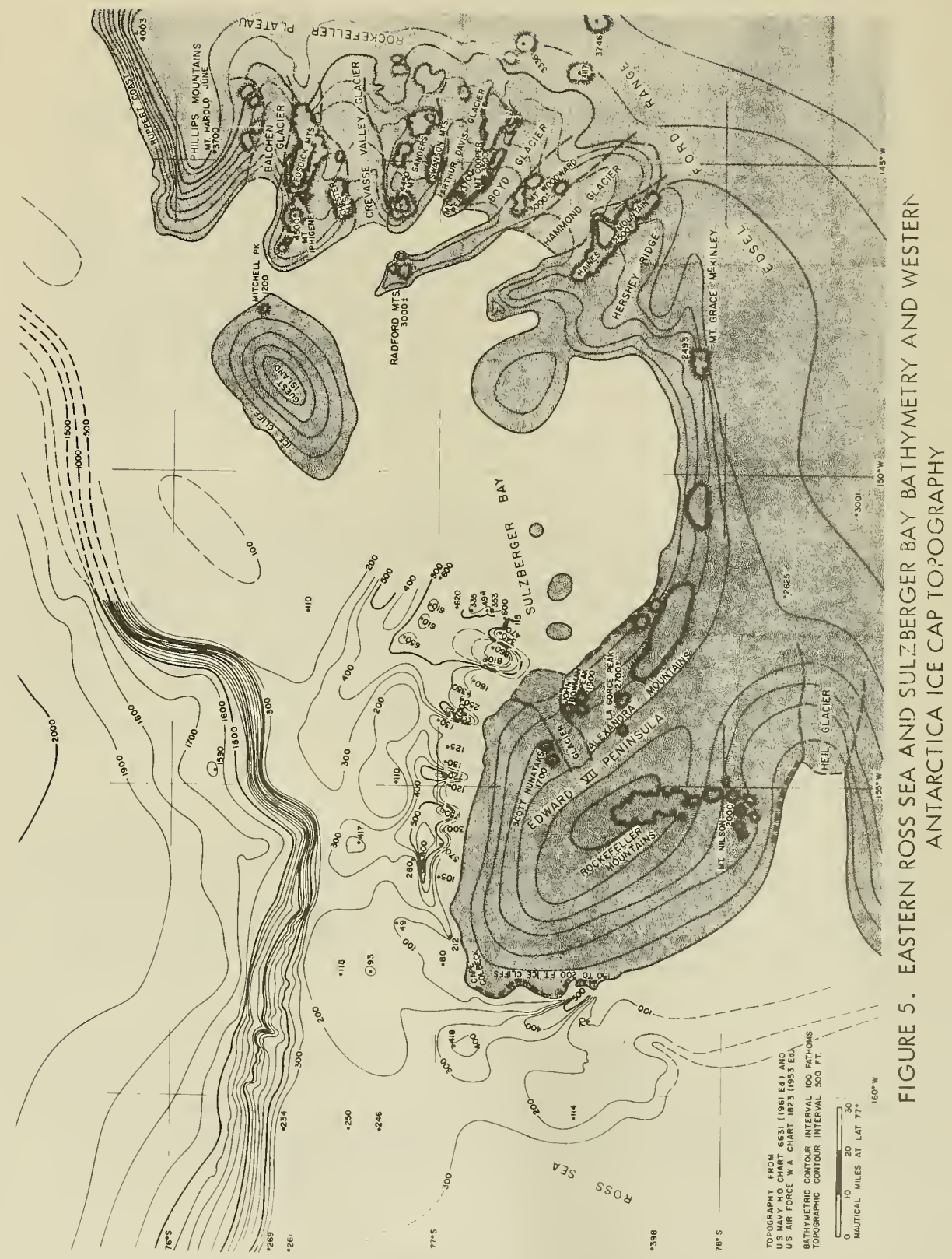


The canyons In Profile A-B are probably deep notches cut into the south wall of the longltudinal depression and into its bordering Inner shelf, the 130-fathom flat ropped crests between the notches.

A broad, tongue-shaped trough extends southeast from just inside the shelf break landward through Sulzberger Bay, where it finally disappears under the ice shelf. This trough shown on Figure 2 and Profiles E-F and J-K (Fig. 4) is called the transverse depression after Holtedahl (1958). The walls of the depression appear to have comparatively moderate curving slopes, and the deeper parts of its floor are between 550 and 650 fathoms.

Shelf depressions also are found adjacent to the western coast of Edward VII Peninsula (Fig. 2); further south the USS GLACIER recorded a near-shore depression which is probably related to a north-south depression described by Crary, et al (1962) that continues south under the Ross Ice Shelf parallel to and bordering the Ross embayment. Other depressions similar to the longitudinal depressions off Edward VII Peninsula undoubtedly exist along the northwestern shores of Guest Island and Ruppert Coast (Fig. 2). Although no sounding data were collected to substantiate this, Byrd (1933) noted that thick icebergs floated freely when they broke from ice cliffs off these shores and did not become grounded until they had traveled some distance from shore.

\section{Shelf Ridges}

The submarine moraine-like ridges found on the continental shelf of the eastern Ross Sea-Sulzberger Bay area are either transverse or parallel to the general trend of the shoreline and, accordingly, will be referred to as transverse or longitudinal ridges (Figs. 2 and 5).

The transverse ridge extending north from Cape Colbeck appears to be superimposed on the inner shelf, the longitudinal depression, and the outer shelf. As shown by Profile $A-B$, Figures 2 and 3 , the ridge is asymmetrical - its crest is closer to its eastern edge. The shallowest sounding, 49 fathoms (shown on Figure 5), north of Cape Colbeck, was obtained by Roos (1937) near grounded icebergs.

Another transverse ridge extends westward from the western shore of Edward VII Peninsula (Fig. 2). This ridge, like the other, appears to be superimposed on the inner shelf, the depression, and the outer shelf. Its 70-fathom crest is serrated by a series of deep, half-mile-wide notches.

A longitudinal ridge, seaward of the longitudinal depression off the north shore of Edward VII Peninsula (Fig. 2), was indicated by soundings made by GLACIER in 1961-62. This ridge appears to consist of two broad mounds aligned 
in an east-west direction with its eastern end terminated by the trough of the transverse depression.

Another longitudinal ridge, northwest of Guest Island, is outlined by the dashed 100-fathom contour (Fig. 5). The only soundings on this ridge were obtained ot its western end, where the ridge blends into the east wall of the transverse depression; however, the northeast extension of the ridge was based on the locotion of grounded icebergs reported by Byrd (1933). A large grounded iceberg shown on H. O. Chart 6637 (U.S. Navy 1961) was the basis for the position of another longitudinal ridge farther to the northeast off the Ruppert Coast.

\section{BOTTOM SEDIMENTS OF THE EASTERN ROSS SEA AND SULZBERGER BAY}

The Deep Freeze 61 Phleger cores taken by STATEN ISLAND in the eastern Ross Sea and Sulzberger Bay are now under study by Dr.H.G. Goodell at Florida State University. Preliminary field analyses of these samples indicated they are composed of submarine glacial till. Most of the samples appeared to be uniform in texture; the only noticeable exceptions have evidence of ice-rafted pebbles. The field descriptions with. corresponding depth soundings of 25 STATEN ISLAND cores and 6 GLACIER (TR 33, U.S. Navy Hydrographic Office, DEEP FREEZE I, 1956) cores are shown on Figure 2.

In the GLACIER cores, the sphericity of the particles of sediment generally was low, and the particles were mainly subangular to angular, some had rough, polished surface texture. All were considered to be glacial marine till. Pebbles and larger rock particles were found near the Ross Ice Shelf. In the GLACIER samples from the deep depressions, sand-size particles were scarce. The highest clay-size content was found at GLP-2 at 730 fathoms in the longitudinal depression. Rock fragments in the cores consisted of schist, slate, graywacke, quartzite, scoria, pumice, volcanic glass, fine-grained volcanic fragments, coarse-grained granitic fragments, and chert. The source of these fragments was probably the Edsel Ford and Rockefeller Mountains. The petrology of this landmass is described by Passel (1945), Warner (1945), and Wade (1945). 
The origin of geomorphology of the submarine topography features shown on Figure 5 can best be discussed after reviewing the areal geology, present sedimentation, and present and prior glaciation of the area under consideration.

\section{A. Areal Geology and Glaciology}

The geology, geomorphology, and glaciology of the land masses bordering the eastern Ross Sea and Sulzberger Bay have a direct bearing on the Pleistocene history of the adjacent continental shelf.

Figure 5 shows the outline and the surface topography of the ice cap and its outlet glaciers, the trends and elevations of the protruding rock outcrops, and the names and elevations of the mountains. Figure 2 shows the approximate position of the rapidly changing front of the present floating ice shelves.

According to Wade (1937), the Edsel Ford Mountains are folded, partly metamorphosed sediments with concordant granite intrusions that probably preceded complete folding. The beds are mostly vertical and strike NW-SE in the south end of the range, but their strike swings through N-S to NNE in the northern part. Folding and faulting are closely related. The sediments are folded into broad anticlines and synclines; the axes trend NW and plunge $30^{\circ}$ to $40^{\circ}$ in the same direction (Warner, 1945). Passel (1945) noted some sediments exceeded 15,000 feet, and he also found basic lavas and ash along the axis of Fosdick Range that he considered as evidence of fairly recent volcanic activity because the volcanic cones apparently had not been overridden by the Pleistocene ice advances as were the rocks upon which the cones are situated.

The Rockefeller Mountains according to Wade (1945) appear to be metamorphosed sediments that have been intruded by a granitic batholith that structurally and petrographicallyresembles the Edsel Ford Range. The fold axes trend NW-SE.

Fairbridge (1952) contends that Edward VII Peninsula appears to be separated from the Edsel Ford Mountains by block faulting. A seismic profile across Marie Byrd Land by Thiel and Ostenso (1961) indicates the presence of a large depression in the sub-ice bedrock. This depression is aligned southeast of the bight of Sulzberger Bay. A deep glacial trough is incised into the floor of Sulzberger Bay in a SW direction along this same line. The rock outcrops near the SW edge of the bay also trend SE. 


\section{B. Present Antarctic Marine Sediments}

The chief features that characterize recent Antarctic sedimentation, according to Lisitzyn (1962), are:

1. Almost complete absence of runoff.

2. Little chemical weathering; most water on the continent is in a solid state.

3. Negligible role of wave erosion; the ice shelves and sea ice, which together surround the continent, effectively dampen wave mation.

4. Recent volcanic activity.

5. Little chemical precipitation; the low temperatures of the water inhibit precipitation of $\mathrm{CaCO}_{3}$.

6. Glacial erosion and the seaward movement of glacial ice are the chief factors responsible for the removal of material from land and its subsequent deposition as marine sediment.

7. The luxurious growth of phytoplankton, especially near the ice edge; diatoms are the chief source of organic matter in the sediments.

8. The rugged topography upon which the sediments are accumulating; these sediments are distributed by oceanic currents after they are dropped by floating ice.

Most of the sedimentary material in Antarctica accumulates away from the coasts in the zone of maximum deposition by icebergs. Consequently, most of the glacial marine sediment falls 100 to 200 miles from shore on the outlying parts of the continental shelf, on the continental slope, and on the continental rise. This is explained by the fact that most of the melting of the icebergs occurs in the warmer waters away from shore. Inshore, where sedimentation is slower, the shelf has a rugged topography, almost bare of sediments (Lisitzyn, 1962).

A 7.6-mieter core, reported by Hough (1950) to penetrate to sediments of Nebraskan age, was obtained from the continental rise in the Ross Sea. Even if the age of the Nebraskan glacial advance were assumed to be 300,000 years (after Fairbridge, 1961) rather than 700,000 years (after Hough, 1950) deposition of 8.0 meters (correcting for $5 \%$ compaction by the coring device) would give an average sedimentation rate of only 2.7 centimeters per thousand years. This represents, by extrapolation, only 90 feet of sediment during the entire Pleistocene epoch in this zone of maximal sedimentation seaward of the continental shelf.

According to Evteev (1959), the average annual rate of bedrock erosion by the ice cap is nearly the same as that by rivers on temperate continents. 
Surficial sediments of the Antarctic continental shelf are composed primarily of ice-rafted material (U. S. Navy, 1957); these iceberg sediments form a belt 200 to 600 miles wide (Lisitzyn, 1962) as compared to an average shelf width of only 105 miles (Noronov, 1960).

These separate lines of evidence indicate that Pleistocene sedimentation of the Antarctic continental shelf has been rather slow .

The outer limit of the zone of glacial marine sediment is correlated with the maximum extent of pack ice, i.e., frozen sea water. Seaward of this zone is a circumferal 600- to 1,000-mile-wide zone of diatom ooze (U.S. Navy, 1957; Lisitzyn, 1962). For the most part, diatoms are restricted to the cold, less saline surface waters which extend from the Antarctic coast to the Antarctic Convergence, where they meet the warmer, more saline waters farther north.

"Clay" (glacial rock flour?) and diatomaceous clay oozes are spread on the Antarctic continental rise. These consist of fine glacial sediments and diatom debris discharged in large amounts from the continental shelf (Zhivago and Lisitzyn, 1957). Long cores from this peripheral area show alternations of green-brown clay and diatomaceous clay ooze with typical diatomaceous sediments. According to Lisitzyn (1962), these repeated changes in sediment types prove that climatic changes have taken place during Quaternary time. As a result of these changes, the boundaries of the main sediment types have shifted northward and southward more than 500 miles. At the present time, a substantially warmer period exists in the Antarctic zone. Hough (1950) interprets in a similar manner the alternations of coarser glacial marine sediment with fine-grained "nonglacial "sediments of a core from the continental rise bordering the Ross Sea. Many of the core samples of the eastern Ross Sea - Sulzberger Bay area also showed similar fine and coarse alternations (Goodell, unpublished analysis; Goodell et al., 1961).

In brief, the surficial sediments of the continental shelf are composed primarily of mechanically disintegrated material, i.e., rock flour, fragments, and larger erratics, all of which have been ice-rafted from land. The sediments are unsorted, unaltered, and low in organic matter (U.S. Navy, 1956). Diatoms make up a large part of the organic matter (Lisitzyn, 1962).

\section{Present Glaciation}

From his field work in the area, Wade (1937) found that the Edsel Ford Range acts as a 150-mile-long barrier to the continental ice cap of the Rockefeller Plateau to the east. The rock outcrops occur in NW-trending mountain chains (Fig. 5). Their present configuration is the result of folding, tritrusions, and glaciation. The sub-ice topography of the northeast shoreline of Sulzberger Bay would be a series of fjords if the ice was removed. 
Ice now covering Edward VII Peninsula appears to thin out in all directions from the center where it is 2,100 feet thick and 3,200 feet above sea level (Byrd, 1935). The western shoreline of Sulzberger Bay is characterized by steep slopes where the ice moves down to the bay between the peaks of the Alexandra Mountains. Area tension cracks on these slopes are quite numerous, reflecting, perhaps, a steepening of the slope of the surface of the underlying bedrock. Large undulations lead out from these disturbed areas, eurving north toward the head of the bay indicating direction of differential movement within the floating ice shelf (Wade 1937a, p. 587).

The present ice surface south of Sulzberger Bay forms an E-W ridge. Its crest rises toward the Rockefeller Plateau (Behrendt, et al., 1962). Since, according to Nye (1959), ice flows over large areas in the direction of the slope of the ice surface, ice north of the crest flows into Sulzberger Bay, ice south of the crest flows south and then west into the Ross embayment to become part of the northflowing Ross Ice Shelf.

The present ice sheets affecting the Sulzberger Bay area have their accumulations on Edward VII Peninsula (Wade, 1937a), on the Rockefeller Plateau, and perhaps on the interconnecting ice crest.

D. Prior Glaciation

Wade (1937) found considerable evidence of a period of glaciation much greater in extent than presently occurs along the crest of the Edsel Ford Range. For example, on the rather flat crest of Mt. Woodward he found chattermarks and crescentic gouge marks 600 feet above the present level of valley glaciers. The Rea-Cooper massif, 2, 800 feet above the level of the shelf ice, has a U-shaped valley cutting across one of its higher peaks which implies a former active glacier high enough to overflow the massif at least 2,000 feet higher than the nearest active ice today.

Wade (personal communication, 1963) thought the former ice over Edsel Ford Mountains was probably no less than 1,000 feet thicker than the present ice sheet.

The Ross Ice Shelf, which now floats over its basal moraine (Poulter, 1947; Carey and Ahmad, 1961), may at one time have been a grounded ice cap extending past the present ice barrier to the edge of the continental shelf (Hollin, 1962) Noronov 1960). Roos (1937) and Taylor (1930) have considered Pennel Bank, near the seaward edge of the continental shelf of the Ross Sea, to be a terminal moraine. 


\section{DISCUSSION}

The geomorphology of the submarine topographic features of the eastern Ross Sea and Sulzberger Bay is discussed here in the light of the probable glacial history of the area. All of the categories of bathymetric features found on the continental shelf of the Sulzberger Bay area are also found on other continental shelves off glaciated regions of both hemispheres (Holtedahl, 1958; Shepard, 1948; Zhivago, 1962). Explanations proposed for their origins should therefore be generally applicable (rather than unique) as far as factual data permit.

\section{A. Outer Shelf}

Soundings on H. O. charts nos. 6636 through 6646 (U. S. Navy, 1960-61) show that the outer edge of the continental shelf lies at 200 to 300 fathoms or more around the entire continent, except where it is transected by other features.

Surf-base erosion during eustatic sea level drops associated with Pleistocene glacial advances could not alone have caused this great shelf depth. The lowest glacial sea level was less than 100 fathoms below the present sea level (Fairbridge, 1961; Donn, Farrand, and Ewing, 1962). Thus, the low sea levels of Pleistocene glacial maxima stood at less than one-half of the depth needed for surf-base planation of the outer shelf to its present depth.

1. Eustatic, Isostatic, and Glacial History. According to Nichols (1960), no substantial evidence of Tertiary glaciation of Antarctica has been discovered. The reconstruction of the probable glacial history of the continental shelf will, therefore, open with some remarks on Pliocene sea levels.

Fairbridge (1961, figure 5, p. 119) shows Pliocene sea levels ranging from 10 to 100 fathoms above the present sea level. Additionally, Dietz and Menard (1951) cite bathymetric evidence to show that wave-base planation is non-existent and that shelf planation is caused by surf action at shallow depths of less than 5 fathoms.

From this, the Pliocene shelf break in Antarctica is assumed, by this writer, to have been near what is now sea level, i.e., 200 to 300 fathoms shallower than the present shelf break.

According to Hollin (1962), the Antarctic ice sheet probably existed throughout the Pleistocene ond the regime of the ice sheet has remained highly positive (98 percent of the accumulation on the grounded ice sheet reaches the sea and remains to be consumed by it directly from coastal ice cliffs or indirectly from floating ice shelves). Because of this, the area of the ice sheet is determined 
chiefly by the elevation of the "grounding line," where the peripheral ice cliffs and ice shelves begin to float (Hollin, 1962; Voronov, 1960). During glacial stages of the Northern Hemisphere, the consequent drops in sea level displaced the grounding downward and northward, and allowed the ice sheets to advance to the outer boundaries of the continental shelf (Noronov, 1960).

This "grounding line" concept brings out a very important point. It shows that the glacial history of the Antarctic periphery is governed not so much by climate as by sea level changes. Thus, the Antarctic glacial fluctuations were dependent on, and more or less in phase with, those of the Northern Hemisphere.

Corroborating this argument, Hough's age dating $(U, \mid 0, R a)$ of sediment cores from the Ross Sea and from the South Pacific Ocean strongly indicates an in-phase correlation with the last two glacial advances in the Northern Hemisphere (Hough, $1950 ; 1953)$.

According to Voronov (1960) and Hollin (1962), the general surface profile of the Antarctic ice cap is determined, above all, by the viscous and plastic properties of the underlying ice. The remaining factors (sub-glacial relief, quantity and distribution of accumulation, marginal ablation, temperature changes, etc.) which may affect the shape of the ice sheet are of secondary importance and do not materially affect its profile. Hollin found that the parabolic curve

$$
h=4.7 \sqrt{d}
$$

(where $d$ is the distance from the edge of the ice sheet in meters and $h$ is the height of the ice sheet from sea level in meters) fits the observed profiles as for as 200 miles from the ice edge.

If the grounded ice sheet of Edward VII Peninsula were to advance 35 miles secentard to the continental shelf edge from the present ice edge, a consequent vertical increase of about 4,000 feet of ice over the present shorellne would be indicated by the formula. A greater increase in thickness would occur over the southern Edsel Ford Mountains, because they are farther from the shelf edge.

All of the peaks visited in the Rockefeller Mountains and in the Edsel Ford Range showed conclusive evidence that they had been overridden by an ice sheet (Wade, 1937). An additional 1,000 feet is believed to be a reasonable minimum figure for the thickness of ice necessary to result in overriding (Wade, personal communication).

Hollin (1962) concluded, from the highly positive regime of the Antarctic ice sheet and from mechanics of the ice, that, once the continental ice sheet was established at the beginning of the Pleistocene, the ice in the interior did not 
fluctuate appreciably. The prevailing isostatic equilibrium of the interior continental platform of both East and West Antarctica (Woollard, 1962) supports Hollin's conclusion.

The advance and retreat of the Antarctic ice sheet over a peripheral zone would cause isostatic depression and rebound of this zone. Assuming no crustal shear strength, Weertman (1961) proposed an isostatic crustal depression of 330 meters for every 1,000 meters of overlying ice of large ice caps. But, as the earth's crust does have shear strength, the area of depression would be spread to about 65 miles beyond the loaded area (Gunn, 1943, 1949). Therefore, the zone of isostatic movement of the periphery of Antarctica would be less than that calculated when neglecting crustal shear strength.

Hollin (1962, p.89) referred to "isostatic restraint," a factor whereby isostatic depression by the advancing ice front would cause a relative rise of sea level which would in turn tend to counteract the eustatic drop of sea level which initioted the ice advance. Hollin assumed that the time lag between glacial adjustment to sea level and isostatic compensation is small compared to the periodicity of the fluctuations. He thereby objected ( $p .187$ ) to Voronov's contention that the ice advanced all the way to the continental shelf edge - "isostatic restraint" would limit the ice advance to lesser distances.

Fairbridge (1961, p.127), however, on the basis of paleoshoreline studies, age-dating, and geodetic and gravity measurements found that "complete" isostatic adjustment would take about three times as long as complete glaciation. Heiskannen and Vening Meinesz (1958, p.369) gave the formulae:

$$
t_{r}=\frac{6.3}{L}
$$

fwhere $t_{r}$ is the relaxation time in thousands of years during which the deviation from isostasy diminishes to $1 / \mathrm{e}$ of its value over an infinitely long depression of width $\underline{L}$ in thousands of kilometers) and

$$
t_{r}=6.3 \frac{L M}{\sqrt{L^{2} M^{2}}}
$$

(where the second horizontal dimension is $M$ in thousands of kilometers). Taking 20,000 years as the time elapsed since the last glacial maximum (Fairbridge, 1961; Curray, 1961), this writer estimates, from the above formulae, that the coastal zones of glacial isostatic depression are now only about 35 percent compensated. Broader areas of ice fluctuations such as the Ross embayment are now accordingly about 60 percent compensated.

The above calculations and Fairbridge's dating of the Pleistocene cycles (circa 22,000 year half-cycles) lead the author to believe that the peripheral 
continental crust of Antarctica would not have achieved more than 30 to 70 percent isostatic compensation in either direction after the initial onset of the Pleistocene fluctuations. The considerable time lag of isostatic sea level changes behind eustatic changes minimizes the isostatic restraint of ice advance and thus seems to overcome Hollin's (1962) objection to Voronov's (1960) assertion of a shelf-break boundary for Antarctic ice sheets of glacial maxima.

With the above considerations in mind, the writer offers the following approximate reconstruction of eustatic, isostatic, and glacial interactions:

a. With the initial onset of Pleistocene glaciation, the Antarctic ice sheet advanced to the outer edge of the then-shallow continental shelf. The eustatic lowering of sea level, caused by storage of water in ice caps of both hemispheres, more than kept pace with the slower isostatic depression of the shelf.

b. Then, as the sea level rose eustatically with the melting of Northern glaciers and rose (more slowly) by isostatic depression of the shelf under the ice load, the Antarctic ice sheet would be forced to retreat landward, leaving the continental shelf lying unusually deep (as it now does).

c. The shelf would then rise toward adjustment.

d. The cycle repeated with the next glacial advance. Probably, several glacial advances and retreats closely followed the eustatic sea level oscillations initiated by the Northern glacial cycles of the Quaternary ice ages.

Antarctica is generally considered to be in an interglacial period (Hough, 1950, 1953; Hollin, 1962; Crary, et al., 1962). The writer assumes that, during previous interglacial stages, Antarctic climates were then also "polar" and without rivers, surf, etc.

The rugged topography of the inner shelf areas near the present ice cliffs was interpreted by Zhivago (1962) as evidence of the small quantity of marine sedimentation. This can be explained by the below-freezing temperature of glacial ice along mony parts of the coast. Icebergs cannot drop sediment until they have warmed to melting temperatures farther seaward. These considerations of sedimentation do not include the great shelf embayments under the presently-floating Ross and Filchner ice shelves (Fig. 1).

As the continental shelf apparently bore the weight of thousands of feet of ice during periods of glacial maxima, it might be expected that the thinly-covered Tertiary sediments would have been eroded or at least compacted by the overriding ice sheets. Thereby, a progressive overall lowering of the shelf surface (superimposed upon the cyclic isostatic and eustatic effects) may have taken place since the inception of the Pleistocene ice ages. This progressive shelf-lowering due to ice erosion, compaction, and deficiency of sedimentation would tend to offset the progressive lowering of glacial sea levels noted by Fairbridge (1961). 
It appears to the author that the isostatic rebound of the Antarctic continental shelf has barely begun since the retreat of the ice sheet of the last glacial maximum. Near McMurdo Sound, where at least 2,000 vertical feet of ice have been removed, the highest raised beaches reported are only 66 feet above present sea level (Nichols, 1961). The gravity deficiency over a section of the continental shelf in Eastern Antarctica (Ushakov and Lazarev, 1959) may be further evidence of remnant crustal downwarp.

Assuming that the latest major retreat of the ice front in Antarctica was governed in part by the rise in eustatic sea level, which was in turn caused by the retreat of northern glaciers, it seems to this writer that some lag in southern glacial retreat and rebound can be expected. More important, the Antarctic ice sheet has differed from northern ice caps in the following ways:

a. The Antarctic ice cap is centered over a geographic pole, whereas the Pleistocene ice sheets of the Northern Hemisphere were not.

b. The mass budget of the Antarctic ice sheet has remained strongly positive whereas that of northern ice sheets was positive only during their advances. As northern ice caps ended chiefly on land, the ablation at their edges must have been considerable even as they grew. On the other hand, surface ablation of Antarctic ice sheets is unimportant (Hollin, 1962), even in the present interglacial period.

c. The edge of the Antarctic ice cap has periodically migrated over the relatively narrow zone of the continental shelf. The ice loading of this peripheral zone has been large in magnitude and duration due to the steep ice surface profile and the proximity of the polar ice to this zone during interglacials. The time intervals of ice loading on northern continents have been relatively fleeting due to the greater distances of glacial advance and retreat. Ice loading of most of the northern continents has been absent during interglacial periods.

As a consequence of these differences, this writer believes that the isostatic depression of the continental shelf of Antarctica has been greater in vertical magnitude than that of continental shelves off glaciated areas of the Northern Hemisphere.

2. Origin of the Outer Shelf - Summary and Conclusions. The author attributes the great depth of the outer shelf to factors which may explain the great depth of the entire Antarctic continental shelf as well as the deeper-than-average depths off other glaciated coasts. These factors, in order of their importance, are:

a. Remnant isostatic depression from ice loading of the latest (Wisconsin?) advance of the grounded ice sheet over the continental shelf. The glacial advances and retreats were controlled by eustatic sea level changes. Isostatic 
recovery of the Antarctic continental shelf has lagged behind isostatic rebound in the Northern Hemisphere. The narrower zone of crustal ice-loading and unloading in Antarctica has been depressed to greater extents over longer intervals of time than have the broader zones of glaciated continental margins in the Northern Hemisphere. Isostatic adjustment of the outer shelf of Sulzberger Bay may be considerably less than half completed at present. Geomorphic evidence of extensive former ice advance cantrasts with evidence of a comparatively small amount of rebound.

b. Glacial compaction of Tertiary and interglacial marine sediments of the outer shelf seems likely in view of the probability that the shelf surface bore a great weight of ice.

c. Glacial erosion of the shelf surface by grounded ice may have taken place.

d. The rate of Pleistocene marine sedimentation of the continental shelf has been slow because most of the ice-rafted sediment seems to have been deposited beyond the outer shelf.

\section{B. Shelf Depressions and Inner Shelf}

The deep, trough-like depressions found within the continental shelf surface of the Sulzberger Bay area are not unique. Examination of H.O. charts 6636 (U. S. Navy 1960-61) shows deep transverse and longitudinal depressions in the continental shelf surface along all sides of the Antarctic coast. Most of these great troughs hove a minimum relief of 100 fathoms and frequently reach depths of 500 fathoms near the shore side of the shelf. These depressions often occur in clusters of longitudinal depressions near shore together with transverse depressions whose floors slope upward as they approach the outer edge of the shelf. These clusters of depressions are bounded on their inner sides by steep-sided, relatively shallow inner shelves across which they frequently extend to connect with existing ice streams ("glaciers" on charts). The outer sides of the depressions are bordered by moraine-like mounds or ridges which often have reliefs of 100 fathoms above the shelf surface. The transverse depressions usually transect these ridges at the outer shelf, but appear not to cut through the shelf break at their seaward ends.

Zhivago and Lisitzyn (1957) discuss the "inner shelf depressions" in the Antarctic continental shelf adjacent to the Indian Ocean. Holtedahl (1958) and Shepard (1948) have noted strikingly similar depressions and banks of the glaciated coasts of the Northern Hemisphere. (The interested reader can compare Zhivago and Lisitzyn's Figure 4 (1957), Holtedahl's Figures 1 through 6 (1958), and Figures 2 through 5 of this paper). 
1. Transverse Depression. As will be pointed out in succeeding paragraphs, it is probable that the large broad-based trough which extends from under the floating ice shelf of Sulzberger Bay seaward to a point near the outer shelf break (Fig. 2) is an ice-carved feature.

Odell (1937) concurred with Wright and Priestly (1922) that the ice covering of the continent has a predominantly conservative effect; it is only where the outflow glaciers (e.g., "ice stream" where outward movement of continental ice is accelerated) acquire a certain critical velocity that they can be considered eroding agents comparable with other geologic forces. Flint (1957) gives many examples (Northern Hemisphere) of deep glacial troughs carved by an ice cap with little or no erosion in adjacent areas covered by it. Flint concludes that the effectiveness of glacial erosion varies greatly, both from place to place and from time to time, with rate of flow, thickness of ice, basal load, and erodability of the ground.

Mellor (1959) estimates that ice streams, which occupy o small fraction of the total length of the Antarctic coast, are responsible for the removal of more ice from the continent than the "sheet flow" (the general outward movement of the continental ice) over the remaining length of the coast.

Shepard (1931, 1948) points out that glacial troughs differ from typical submarine canyons in their:

a. great width;

b. trough shape, i.e., steep walls and broad base;

c. straight or smoothly curving sides;

d. undulating longitudinal profile;

e. depths in the inner (landward) portions of the valleys comparable with or greater than the depths in the outer (seaward) portions of the valleys; basin depressions.

Shepard's description of glacial troughs fits the transverse depression of Sulzberger Bay.

From the foregoing glaciological and topographic considerations, it appears to this writer that the transverse depression of Sulzberger Bay was carved or deepened by a former ice stream.

Fairbridge (1952) suggests that the Edsel Ford Range is separated from Edward VII Peninsula by block faulting. Thiel and Ostenso (1961, Fig. 1) show a deep, 3,000-foot trench or depression in the bedrock below the ice cap about 100 miles southeast of the southern Edsel Ford Range, in line with the transverse depression of Sulzberger Bay. The bathymetric contours of Figure 5 show a major concavity off the edge of the continental shelf block adjacent to the seaward end of the transverse depression. A NW-SE line can be drawn through these three features. The 
topographic expression and structural axes of the Edsel Ford Mountains and the Alexandra Mountains on either side of this line also trend NW-SE.

The writer suggests that the transverse depression of Sulzberger Bay is the result of structurally controlled erosion along a major fault zone by an ice stream during periods of glacial maxima.

2. Longitudinal Depressions and the Inner Shelf. The longitudinal depression and its bordering inner shelf parallel to the north shore of Edward VII Peninsula (Fig. 2) seems to be similar to the "inner shelf depressions" and "hilly shelf" off East Antarctica described by Zhivago and Lisitzyn (1957) and to the longitudinal depressions and inner shelves off Norway, Labrador, and Alaska described by Holtedahl (1958).

Zhivago and Lisitzyn (1957) suggest that the longitudinal depressions off East Antarctica were caused by a major fracture at the edge of the continent which occurred as a result of vertical movements of the mainland. Zhivago and Lisitzyn (1957) relate the vertical tectonic movements of the mainland with changes in its glacial load, and point out that the primary disjunction of forms is only slightly leveled by marine sedimentation.

Holtedahl (1958) suggests that the longitudinal channels along glaciated coasts of the Northern Hemisphere represent major crustal fracture zones, with a downdrop of the outer, deeper shelf relative to the inner shelf. He points out that, to account for the great depressions as being formed by ice erosion, one would have to assume that this outer part of the shelf consists of rocks very different in lithologic character from those of the inner shelf area - viz., either very soft rocks or with a great concentration of fractures.

Shepard (1948) suggests that glacial erosion of the sea floor may have been more effective than erosion within the continent because the rock of the continental shelves appears to be softer, in general, than that of the continental masses. Holtedahl (1958) points out that, even on this assumption, the abrupt drop from the level of the inner shelf at a depth less than 100 fathoms (off Labrador, in this cose) to the inner deep of the transverse depression at a depth of over $\mathbf{4 5 0}$ fathoms over a distance of about five kilometers seems to suggest factors other than ice erosion contributed to its formation.

Off Edward VII Peninsula, the depth drops from 130 fathoms to over 600 fathoms over a distance of as little as one mile (Fig. 5 and the southwest end of Profile C-D, Figs. 2 and 3). 
The general direction of the longitudinal depression is at right angle to the general direction of ice movement. Holtedahl (1958), commenting on this same relationship in the Northern Hemisphere, suggests that valleys of considerable depth may have existed prior to glaciation.

The canyons reported by the USS STATEN ISLAND while steaming close along the northern shore of Edward VII Peninsula (Profile A-B, Figs. 2 and 3) are interpreted by this writer as notches carved into the south wall of the longitudinal depression by ice moving outward from the peninsula. These canyons hove crossprofiles typical of fiords such as those of the west coast of Norway. (In physiographic literature fjords are deep and narrow ice-cut channels with steep sides.)

Holtedahl (1935) states that most typical fjords are found in a highland where existence of older, river-cut valleys caused a concentrotion of ice erosion along certain narrow zones where a bedrock of hard, jointed rocks favored the development of angular design and steep walls. Holtedahl (1935) also states that, if, in similar rocks, there had been no previous river erosion, but glacial erosion had begun, for example, on an undissected plateau surface and its coostal slope, the result is a system of relatively short and broad bays or valleys, such as found on the northwest corner of Spitzbergen and the west coast of Palmer Peninsula, Antarctica.

The outcrops of Edward VII Peninsula show hard, jointed rocks whose structural grain is in the same approximate orientation as are the off-shore canyons. Since most of these canyons of Profile A-B are deep and narrow, and yet do not extend past the longitudinal depression, the application of Holtedahl's (1935) generalizations suggests that the inner shelf was once eroded by rivers, whereas the outer shelf was not. If this is correct, the longitudinal depression (or series of depressions) marks the position of a fault zone along which the uplift of the inner shelf relative to the outer shelf took place before the onset of Pleistocene glaciation.

Wade (1937) proposed that the ice of the northeast shoreline of Sulzberger Bay conceals "a magnificent fjord country." Here too, ice erosion may have been guided by Tertiary river valleys .

The broad-based conyon at the east end of Profile A-B lies directly offshore of a small ice stream labeled "glacier" in Flgure 5. The writer ascribes the origin of this canyon to a former extension of this ice stream .

Northeast of Sulzberger Bay, off Guest Island and Ruppert Coast areas, Byrd (1933) observed and photographed thick (and therefore deep-rooted) icebergs floating freely adjacent to the coast, but grounded farther offshore. His observation opens the possibility of the existence of longitudinal depressions off these coasts. 
As the trend of the longitudinal depressions is at right angles to the general direction of movement of continental ice, such depressions probably mark the position of one of the following:

a. a zone of less resistance to ice erosion caused by either:

1. a major fault zone with downdrop of the outer shelf relative to the inner shelf during the Tertiary or during the Quaternary or

2. a distinct lithology change, the inner wall of the longitudinal depression representing the bedrock surface where it plunges beneath the softer, more recent sediments of the outer shelf.

b. a narrow rift zone of

1. a graben or

2. the steep downbending of the crust along one side of a fault.

It is the writer's opinion that geophysical measurements will be needed to determine the structural significance of the longitudinal depressions.

It appears that Quaternary glacial action has at least aided in keeping these great depressions open, regardless of their structural origin.

\section{Longitudinal Ridges}

The pauses in the Holocene transgression noted by Curray (1961) and others may show their reflections on the Antarctic continental shelf in the form of end moraines. Pennel Bank at the entrance of the Ross Sea and Mawson and Davis Banks off East Antarctica have been interpreted as morainal (Taylor, 1930; Roos, 1937; Fairbridge, 1952; Voronov, 1960; Zhivago, 1962).

The terminal moraines of the ice sheet at its maximum extent were probably shoved over the shelf edge onto the continental slope. In this way, the continental shelf may have been somewhat widened during the Pleistocene.

The longitudinal depression off the north shore of Edward VII Peninsula is rimmed on its outer edge by a longitudinal ridge. The crest of this ridge is approximately 20 miles offshore and lies about midway between shore and the outer edge of the continental shelf. The longitudinal ridge has a gently rounded, irregular surface with a relief of 100 to 200 fathoms above the outer shelf surface. The shoalest sounding, 110 fathoms, was found near the inner edge of the ridge, only five miles from the bottom of the longitudinal depression.

To the northeast, on the opposite side of the transverse depression, is another longitudinal ridge. On the southwest shoulder of this ridge, a core sample was 
obtained (Sample GLP-4, Fig. 2). This sample contained angular to subangular metamorphic, granitic, and volcanic rock fragments, many of them pebble-size and larger. The northeastward extension of this ridge was deduced from the chronic presence of grounded icebergs over the area. It seems probable that grounded lcebergs may have scraped away the veneer of marine sediment, exposing morainal material of longitudinal ridges.

On the basis of the following observations, the longitudinal ridges of the Sulzberger Bay area are interpreted by the writer as end moraines formed by the continental ice sheet during a pause in its retreat during the Holocene transgression:

1. Glaciological and eustatic considerations point to the probability that ice sheets of glacial maxima advanced to the continental shelf edge, beyond the line of the existing longitudinal ridges.

2. The similarity of these ridges to those of other areas which have been more thoroughly surveyed and found to be morainal (e.g., Georges Bank Shepard, et al., 1934) indicates that they may be analogous features.

3. The occurrence of the longitudinal ridges at the seaward rims of apparently glacially-carved depressions suggests that the ridges may be the resting place of some of the material scooped out of the depressions.

4. The relief of the longitudinal ridges above the outer shelf surface and their mound-like shape suggests that they have been dumped or pushed onto the outer shelf.

\section{Transverse Ridges}

A sand-covered, current-swept, transverse ridge extends north and northeast from Cape Colbeck. At its narrow shoreward end, it is bordered on the west by the tongue-shaped depression and on the east it is abutted by the longitudinal depression. At its broader seaward end it merges with the outer shelf. Two aspects of the morphology of this ridge are worth emphasizing: (I) it is tangent to the western shore of Edward VII Peninsula, and (2) it appears to be superimposed upon the inner shelf, the longitudinal depression, and the outer shelf.

Another transverse ridge, also sand-covered and current-swept, extends west from the western shore of Edward VII Peninsula. This ridge, like the previous one, is narrow and relatively shallow at its shoreward end. The ridge fans out onto the deeper shelf of the Ross Sea where it appears to end within a few tens of miles. This ridge is abutted on either side by north-south-trending depressions. This second transverse ridge also appears to be superimposed over the inner shelf, a depression, and the deeper shelf. The fact that this ridge is roughty parallel to the front of the Ross lce Shelf (compare Figs. 2 and 5) may be significant. 
About five miles from shore, the narrow crest of the ridge is serrated by a series of notches spaced at intervals of several hundred yords. These notches have a maximum relief of 40 fathoms. The shallowest depths recorded on the ridge were 70 fathoms. These notches may have been cut by the roots of icebergs dragged over the ridge by the three-knot ocean current .

1. North-South Transverse Ridge. The author suggests that the western shore of EdwardVII Peninsula and the tangential transverse ridge which extends northward from Cape Colbeck describe a north-south line which, at least during certain recurring stages of the Pleistocene, has marked the boundary between two distinct glacial provinces. West of this border, in the Ross embayment, was the province of "wet-base" glaciers, while east of the border was the province of "dry-base" glaciers. Carey and Ahmad (1961) define a wet-base glacier as one whose base is at melting temperature and therefore has basal melt water; a dry-base glacier as one whose base is below melting temperature.

As an example of a dry-base glacier, Carey and Ahmad (1961) cite the Penchsokkia Glacier (on the Atlantic coast of East Antarctica at approximately $10^{\circ} \mathrm{W}$ longitude) and its floating iceshelf; the Ross Ice Shelf is cited as an example of a wet-bose glacier.

Where dry-base glaciers impinge upon the sea, they have a sharp break in surface slope at the line of buoyancy. At the grounding line, the thickness of the floating side decreases abruptly by a factor of four to five. At this transition zone, dry-bose ice about 3,000 feet thick becomes buoyant in water 2,500 feet ( 420 fathoms) deep and thins rapidly to less than 600 feet leaving well over 300 fathoms of open water beneath it, yet the 3,000-feet-thick grounded ice is still resting firmly on an only slightly shallower bottom (Carey and Ahmad, 1961; Robin, 1953).

Wet-base glaciers show little or no surface indication of their grounding line. As a wet-base glacier begins to float, it gradually thins and deposits till at its base. The till still bears part of the weight of the glacier and is dragged or rolled forward to be left where the water depth is just sufficient to give complete buoyancy. Here a submarine slope develops at the angle of repose for the till. By the time wet-base ice reaches the ice borrier where icebergs are calved, little sediment may be left in the ice. The surface of the Ross Shelf is uniform for hundreds of miles even though the shelf is in many places "grounded" to within about seven miles of the outer edge (Cárey and Ahmad, 1961; Poulter, 1947).

It is now thought that the Ross shelf ice is not grounded over much of its area. Where the ice does not touch bottom there is a distinct parallel between rises in the sediment topography and rises in the ice bottom, indicating that a layer of sea water may be able to maintain its thickness despite movement of the ice toward shallower water (Zumberge and Swithinbank, 1962; Crary, 1961). 
The steep surface of the ice moving down the sides of Edward VII Peninsula and the abrupt change of slope where the ice becomes afloat in Sulzberger Bay may indicate that this ice is "dry," i.e., frozen to bedrock where aground. Another indication of the possible dry-base nature of the Sulzberger Bay shelf ice is the presence of dome-shaped ice-mounds (shown as small islands in Figure 2) which may represent banks that the sub-freezing shelf ice touched and froze to. The ice then piled up from lateral pressure and prolonged accumulation of snow. These mounds are mapped as islands because their abllity to remain stable against the pressure of the surrounding shelf ice has indicated that they are more than temporarily grounded icebergs. Byrd (1933) first reported these "islands" in their same positions more than 30 years ago. The front of the enclosing ice shelf has advanced at a rate of many miles per year, shedding icebergs to maintain more or less the same frontal line. Robin (1953) shows similar relationships between the grounded and floating "dry" ice and its underlying topography and bathymetry in the vicinity of Penchsokkia Glacier.

Partially on the basis of studies of ancient tillites, Carey and Ahmad (1961) suggest that wet-and dry-base "glaciers" produce distinct sediment types, as summarized in the following paragraphs.

Wet-base ice produces great thicknesses of unfossiliferous tills that may have occasional sand or mud interbedded and, in particular facies, strongly dragged or rolled structures. These abruptly give place seaward to very different sediments marine sands and silts with rare dropped erratics interbedded with frequent layers of till-like turbidity deposits a few inches to several feet thick. The sediments formed directly below the floating portion of the ice shelf, but beyond its basal moraine, must be turbidites (formed from basal melt water and the steep gradient of till) - unweathered, finely-ground rocks of sand to clay grade. By the time the wet-base ice reaches the ice barrier edge, little sediment may be left in the ice. Crary, etal . (1962) and Zumberge and Swithinbank (1962) note that, as the Ross Ice Shelfmakes its 200-mile journey seaward, melting of its bottom surface and snow accumulation on its top surface eventually replace the original debris-laden terrigenous ice with clean, practically sediment-free ice.

Dry-base glaciers, on the other hand, produce little in the way of tills, but yield marine muds with abundant erratics, all of which have been dropped through water at that distance offshore where the floating portion of the glaciers warm to melting temperature. The grounded zone of dry-base ice at the continental margin does not differ from dry-base ice of the continent, in that the full load of the dry ice laden with debris grinds (and compacts?) the pavement. There can be little sedimentation, if any, in this zone. None of the till-flow and turbidity current phenomena should be expected with dry-base glaciers (Carey and Ahmad, 1961). 
No detailed analysis of the core samples of the glacial marine veneer of the eastern Ross Sea - Sulzberger Bay area was undertaken to test the validity of the writer's proposed division of that area into wet-base and dry-base glaciol provinces. Morphological characteristics of the area, however, suggest such a division.

The sharpness of the submarine topography of the inner shelf and the adjacent and transecting troughs and canyons suggest that only a thin blanket of Quaternary marine sediment exists in the nearshore parts of Sulzberger Bay, indicating that the overriding ice was too cold to drop sediment in this zone.

Seismic measurements show a several-hundred-feet-thick, apparently unconsolidated basal sediment layer under the floating Ross Ice Shelf. These measurements show that the deeper continental shelf surface extends continuously under this basal layer (Poulter, 1947; Crary, et al., 1962).

The transverse ridge extending north from Cape Colbeck has the expected orientation for a lateral moraine of a grounded ice sheet filling the Ross embayment to the shelf edge. If this ridge is indeed a lateral (or medial) moraine, the ice sheet of the Ross embayment must have moved at a different velocity and as a separate unit from the ice sheet occupying the eastern side of the ridge. Since the grounded portion of the Ross ice sheet must have traveled some hundreds of miles farther than its eastern neighbor to reach the shelf edge, it hod a greater opportunity to be warmed to the point of becoming a wet-base glacier, thus changing its mechanical parameters. The drumlin-like surface of the basal sediment under the present Ross lce Shelf (Crary, et al., 1962; Zumberge and Swithinbank, 1962) suggests that the basal sediment has been overridden by grounded ice.

The submarine troughs are found exclusively along the shores of the land mass of the proposed dry-base glacial province. According to the concepts advanced by Carey and Ahmad, these could only have been carved by dry-base glaciers.

2. East-West Transverse Ridge. The orientation of the transverse ridge which extends west from Edward VII Peninsula and parallel to the present Ross Barrier, and the pebbly material found on its back (SI-3, Fig. 2), suggest that this transverse ridge might be the remnant of an end moraine formed by the grounded Ross ice sheet during a pause in one of its advances or retreats. The coarseness of the GLP-6 sediment (Fig. 2) and the disturbed bottom topography in the vicinity (Profile C-D, Figs. 2 and 3 ) may indicate a deposit of turbidite fronting the basal till of the floating Ross Ice Shelf. 


\section{CONCLUSIONS}

The writer's conclusions as to the geologic origins of the submarine topography of the eastern Ross Sea and Sulzberger Boy are summarized below:

A. The outstanding feature of the outer surface of the continental shelf of the Sulzberger Bay area is its great depth of 200 to 300 fathoms. The depth of this terrace is probably due to remnant crustal downwarp caused by ice-loading during the last glacial maximum when the grounded Antarctic ice sheet advanced to the shelf break. Glacial compaction, erosion, and paucity of Pleistocene sedimentation played lesser parts in the lowering of the outer shelf surface.

B. A 600-fathom trough extends from under the shelf ice of Sulzberger Bay toward the outer edge of the continental shelf. The origin of this transverse depression is ascribed to glacial erosion along a major fault zone by an ice stream during glacial maxima.

C. Longitudinal depressions are found parallel to shore and along-side the relatively shallow inner shelf terrace which borders the shore. The longitudinal depressions have probably been carved by sub-freezing ice sheets along zones of less resistance. These zones are parallel to the general trend of the shore line and may represent major fault zones, change in lithology, or narrow zones of crustal movement.

D. The inner shelf represents rocks more resistant to erosion and/or is the upthrown block along the shore side of a fault zone marked by the longitudinal depressions.

E. Longitudinal ridges border the outer edges of the longitudinal depressions . These longitudinal ridges appear to be morainal in nature and may be, at least in part, composed of material scooped out of the longitudinal depressions by former grounded, sub-freezing sheets.

F. The transverse ridge which extends north from Cape Colbeck may be a lateral moraine or a medial moraine deposited between two units of the continental ice sheet when the ice extended to the shelf break.

G. The transverse ridge which extends west from Edward VII Peninsula may be the remnant of an end moraine formed by a grounded Ross ice sheet during a former stand.

In summary, the author concludes that the gross bathymetric features of the continental shelf of the eastern Ross Sea and Sulzberger Bay have been formed by 
glacial erosion and isostatic depression during Pleistocene glacial maxima. The location and orientation of the depressions within the shelf seem to have been controlled by structural features of the shelf. The apparent geomorphic division between the submarine surface of the eastern Ross Sea ond that of Sulzberger Bay may reflect the differences between the regiments of two units of the continental ice sheet which once covered the orea.

\section{ACKNOWLEDGMENTS}

The author wishes to thank Dr. H. G. Goodell of Florida State University and $\mathrm{Dr}$. Ernest $\mathrm{E}$. Angino of Texas $\mathrm{A}_{\&} \mathrm{M}$ University. Dr. Goodell kindly supplied analytical data on DEEP FREEZE 61 Phleger sediment core somples, and Dr. Angino allowed the use of his library on Antarctic literature and directed the author's thesis research. 


\section{REFERENCES}

Behrendt, J.C., R. J. Wold, and F. L. Dowling, 1962. "Ice Surface Elevation of Central Marie Byrd Land." J. Glaciology, vol. 4, no. 31, p. 121-123.

Byrd, R. E., 1933. "The Flight to Marie Byrd Land." Geogr. Rev., vol. 23, no. 2, p. 177-209.

---1935. Discovery, Putnam, New York, p. 313, footnote 16.

Carey, S. W., and N. Ahmad, 1961. "Glacial Marine Sedimentation."

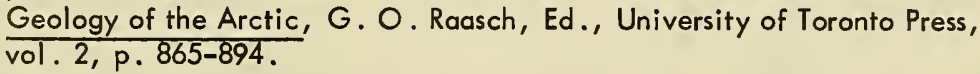

Crary, A. P., 1961. "Marine-sediment Thickness in the Eastern Ross Sea Area, Antarctica." Bull. Geol. Soc. of Amer., vol. 72, no. 5, p. 787-790.

-----, E. S. Robinson, H. F. Bennett, and W. W. Boyd, Jr., 1962. "Glaciological Regime of the Ross lce Shelf." J. Geophys. Res., vol. 67, no. 7, p. 2791-2807.

Curray, J.R., 1961. "Late Quaternary Sea Level: A Discussion." Bull. Geol. Soc. of Amer., vol. 72, no. 11, p. 1707-1711.

Dietz, R. S., and H. W. Menard, 1951. "Origin of Abrupt Change in Slope at Continental Shelf Margin." Bull. Amer. Assoc. Petr. Geol., vol. 35, no. 9, p. 1994-2016.

Donn, W. L., W. R. Farrand, and M. Ewing, 1962. "Pleistocene Ice Volumes and Sea Level Lowering." J. Geology, vol. 70, no. 2, p. 206-214.

Evteev (Yevteyev), S. A., 1959. "Determination of the Amount of Moraine Material Carried by Glaciers of East Antarctic Coast." Infor. Bull. Soviet Ant. Exped. 11, 1959, Leningrad, p. 135-137.

Fairbridge, R.W., 1952. "The Geology of the Antarctic." The Antarctic Today, F. A. Simpson, Ed., Wellington, p. 56-101.

-----, 1961. "Eustatic Changes in Sea Level." Physics and Chemistry of the Earth, Ahrens et al. (eds), Pergamon Press, London, vol. 4.

Flint, R. F., 1957. Glacial and Pleistocene Geology, John Wiley, New York, $553 \mathrm{pp}$. 
Goodell, H. G., W. M. McKnight, J. K. Osmond, and A. S. Gorsline, 1961. "Sedimentology of Antarctic Bottom Sediments Taken During Deep Freeze Four, A Progress Report." Dept. of Geology, Florida State Univ ., 52 pp. (UNPUBLISHED).

Gunn, R. , 1943. A Quantitative Evaluation of the Influence of the Lithosphere on the Anomalies of Gravity, J. Franklin Institute, no. 236, p. 47-65.

-.--1, 1949. "Isostasy-extended." J.Geology, vol. 57, no. 3, p. 263-279.

Heiskanen, W. A., and F. A. Vening Meinesz, 1958. The Earth and Its Gravity Field, McGraw-Hill, New York, 470 pp.

Hollin, J.T., 1962. "On the Glacial History of Antarctica." J. Glaciology, vol. 4 , no. 32, p. 173-193.

Holtedahl, H., 1958. "Some Remarks on Geomorphology of Continental Shelves off Norway, Labrador, and Southeast Alaska." J. Geology, vol. 66, no. 4, p. $461-471$.

Holtedahl, O., 1935. "On the Geology and Physiography of Some Antarctic and Sub-Antarctic Islands." Scientific Results, Norwegian Antarctic Expeditions, 1927-28 and 1928-29, Nosk, Videnskaps Akademi, OsTo, no. 3, 172 pp.

Hough, J. L., 1950. "Pleistocene Lithology of Antarctic Ocean-Bottom Sediments ." J. Geology, vol. 58, no. 3, p. 254-260.

, 1953. "Pleistocene Climatic Record in a Pacific Ocean Core Sample." J. Geology, vol. 61, no. 3, p. 252-262.

Lisitzyn, A. P., 1962. "Bottom Sediments of the Antarctic." Antarctic Research, Geophys. Mono. No. 7, N.A.S. - N.R.C., Wexler, et aT. (eds), Publication 1036.

Mellor, M., 1959. "Ice Flow in Antarctica." J. Glaciology, vol. 3, no. 25, p. 377-384.

Nichols, R. L., 1960. "Geomorphology of Marguerite Bay Area, Palmer Peninsula, Antarctica." Bull. Geol. Soc. of Amer., vol. 71, no. 10, p. 1421-1450.

-_n---, 1961. "Coastal Geomorphology, McMurdo Sound, Antarctica: Preliminary Report." Report of Antarctic Geol. Observ. 1956-1960. 1.G.Y. Glac. Report No.4, Amer. Geogr. Soc., New York, P. 5T-101. 
Nye, J.F., 1959. "The Motion of Ice Sheets and Glaciers." J. Glaciology, vol. 3, no. 26, p. 493-507.

Odell, N. E., 1937. "The Glaciers and Morpholagy of the Franz Josef Fiord Region of North-East Greenland." Geogr. J., vol. 90, no. 2, p. 111-125; no. 3, p. 233-258.

Passel, C.F., 1945. "Sedimentary Rocks of the Southern Edsel Ford Ranges, Marie Byrd Land, Antarctica." Amer. Philos. Soc. pr., vol. 89, no. 1, p. 123-131.

Poulter, T. C., 1947. "Seismic Measurements on the Ross Ice Shelf, Part II." Am. Geoph. Union tr., vol. 28, no. 3, p. 162-170, 367-384.

Robin, G. deQ., 1953. "Measurements of Ice Thickness in Dronning Maud Land, Antarctica." Nature, vol. 171, no. 4341, p. 55-58.

Roos, S. E., 1937. "The Submarine Topography of the Ross Sea and Adjacent Waters." Geogr. Rev., vol. 27, no. 4, p. 574-583.

Shepard, F. P., 1931. "Glacial Troughs of the Continental Shelves." J. Geology, vol. 39, no. 4, p. 345-360.

-----, 1948. Submarine Geology, Harper and Brothers, New York, 348 pp.

----, J. M. Trefethen, and G. V. Cohee, 1934. "Origin of Georges Bank." Bull. Geol. Soc. of Amer., vol 45, no. 2, p. 281-302.

Taylor, T. G., 1930. Antarctic Adventure and Research, Appleton, New York, $245 \mathrm{pp}$.

Thiel, E., and N. A. Ostenso, 1961. "The Contact of the Ross Ice Shelf with the Continental lce Sheet, Antarctica." J. Glaciology, vol. 3, no. 29, p.823-832.

U. 5. Navy Hydrographic Office, 1956. Report on Operation Deep Freeze I, Technical Report 33: Washington, D. C., 81 pp. Appendices.

U.S. Navy Hydrographic Office, 1957. Oceanographic Atlas of the Polar Seas, Part I-Antarctica, H. O. Publication 705, Washington, D.C.

U. S. Navy Hydrographic Office, 1960-61. H. O. Charts No. 6636, 6637, 6638, $6639,6640,6641,6642,6643,6645$, and 6646. Washington, D.C. 
Ushakov, S. A., and G. Y. Lazarev, 1959. "The Question of Isostatic Equilibrium in Antarctica." Infor. Bull. Soviet Ant. Exped. 11, Leningrad, p. 138-143.

Voronov, P. S., 1960. "Attempt to Restore the Antarctic lce Sheet at the Epoch of the Earth's Maximum Glaciation." Infor. Bull. Soviet Ant. Exped. 11, Leningrad, p. 15-19.

Wade, F. A., 1937. "Petrologic and Structural Relations of the Edsel Ford Range, Marie Byrd Land, to other Antarctic Mountains." Bull. Geol. Soc . of Amer., vol. 48, no. 10, p. 1387-1395.

-_---, 1937a. "Northeastern Borderlands of the Ross Sea: Glaciological Studies in King Edward VII Land and Northwestern Marie Byrd Land." Geogr. Rev., vol. 27 , no. 4, p. 584-597.

-_---1 1945. "The Geology of the Rockefeller Mountains, King Edward VII Land, Antarctica." Amer. Philos. Soc.pr., vol. 89, no. 1, p. 67-77.

Warner, L. A., 1945. "Structure and Petrography of the Southern Edsel Ford Ranges, Antarctica." Amer. Philos. Soc.pr., vol. 89, no. 1, p. 78-122.

Weertman, J., 1961. "Equilibrium Profile of Ice Caps." J. Glaciology, vol. 3, no. 30, p. 953-964.

Woollard, G. P. , 1962. "Crustal Structure in Antarctica." Antarctic Research, Geophys. Mono. No. 7, N.A.S. - N.R.C., Wexler et aT., (eds), Publication 1036, p. 53-73.

Wright, C. S., and R. E. Priestly, 1922. Glaciology, British Antarctic (Terra Nova) Expedition, 1910-13. London, $581 \mathrm{pp}$.

Zhivago, A. V., 1962. "Outlines of Southern Ocean Geomorphology." Antarctic Research, Geophys. Mono. No. 7, N.A.S. - N.R.C., Wexler et al., (eds), Publication 1036, p. 74-80.

-.-n--, and A. P. Lisitzyn, 1957. "New Data on the Bottom Relief and the Sediments of East Antarctic Seas." Izv. Acad. Sci., U.S.S.R., Geogr. Ser. No. 1.

Zumberge, J. H., and C. Swithinbank, 1962. "The Dynamics of Ice Shelves." Antarctic Research, Geophys. Mono. No. 7, N.A.S. - N.R.C., Wexler et al ., (eds), Publication 1036, p. 197-208. 
(Security clessilication of title, body of abstract and indexing annotation must be entered when the overall report is classified) 1 ORIGINATING ACTIVITY (Corporate author)

U.S. Naval Oceanographic Office

Oceanographic Surveys Department 2 a REPORT SECURITY CLASSIFICATION Unclassified Ocean Surveys Division

3 REPORT TITLE
SUBM'ARINE ANTARCTICA

4 DESCRIPTIVE NOTES (Type of report and inclusive dates)

Final

December 1960 - March 1961

5 AUTHOR(S) (Last name. first name, initial)
Lepley, Larry K.
(First name not Lawrence)

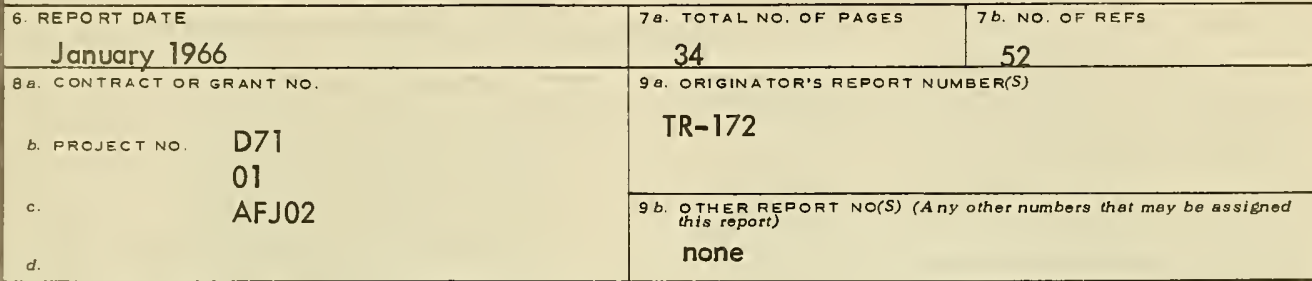

10. A VAILABILITY/LIMITATION NOTICES

Qualified requesters may obtain copies of this report from DCD.

11. SUPPLEMENTARY NOTES
12. SPONSORING MILITARY ACTIVITY

NAVY

13. ABSTRACT

This report graphically describes the submarine topography of the eastern Ross Sea and Sulzberger Bay areas of Antarctica, and explains the origins of the bathymetric features.

The principal bathymetric data used were collected from the U. S. Navy's icebreaker STATEN ISLAND during the DEEP FREEZE 61 reconnaissance survey conducted in December 1960

Recent marine sediments of the Antarctic continental shelf have been rafted from land by ice. A low rate of recent sedimentation on the continental shelf is especially evident at the inner shelf. The prevailing marine sediment of the area is glacial marine till. Hard sand surface occur where strong currents pass over transverse ridges near shore.

The outer shelf break averages about 255 fathoms in depth; the great depth of the outer shelf is attributed to remnant isostatic depression by the continental ice sheet of glacial maxima when the ice extended to the shelf break.

The great ( 600 fathoms) transverse depression of Sulzberger Bay may be the product of erosion during glacial maxima by a locally accelerated "ice stream" whose position was controlled by becrock structure. The origin of the longitudinal depressions can be attributed to erosion by continental ice along zones of weakness due to lithologic changes or faulting parallel to the shoreline

The longitudinal ridges are interpreted as end moraines formed during pauses in the retreat of the continental ice sheet. The transverse ridges are interpreted as lateral and end moraines of a 


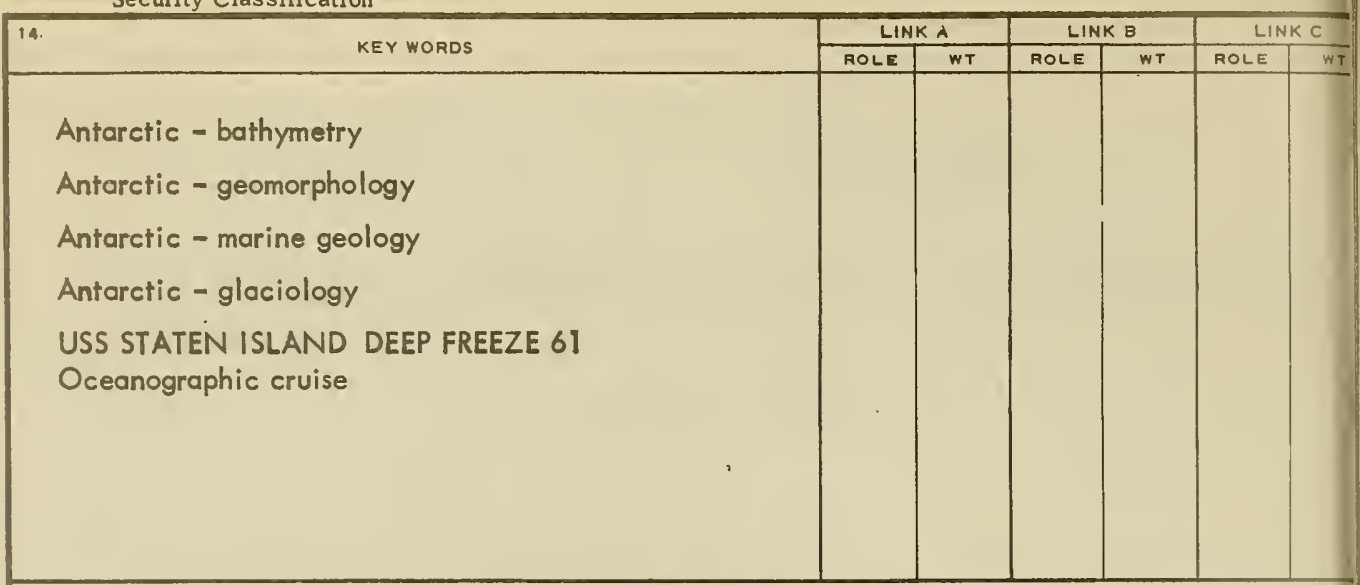

\section{INSTRUCTIONS}

1. ORIGINATING ACTIVITY: Enter the name and address of the contractor, subcontractor, grantee, Department of Defense activity or other organization (corporate author) issuing the report.

2a. REPORT SECURTY CLASSIFICATION: Enter the overall security classification of the report. Indicate whether "Restricted Data" is included. Marking is to be in accordance with appropriate security regulations.

2b. GROUP: Automatic downgrading is specified in DoD Directive 5200,10 and Armed Forces Industrial Manual. Enter the group number. Also, when applicable, show that optional markings have been used for Group 3 and Group 4 as authorized.

3. REPORT TITLE: Enter the complete report title in all capital letters. Titles in all cases should be unclassified. If a meaningful title cannot be selected without classification, show title classification in all capitals in parenthesis immediately following the title.

4. DESCRIPTIVE NOTES: If appropriate, enter the type of report, e.g., interim, progress, summary, annual, or final. Give the inclusive dates when a specific reporting period is covered.

5. AUTHOR(S): Enter the name(s) of author(s) as shown on or in the report. Enter last name, first name, middle initial. If military, show rank and branch of service. The name of the principal author is an ahsolute minimum requirement.

6. REPORT DATE: Enter the date of the report as day, month, year; or month, year. If more than one date appears on the report, use date of publication.

7a. TOTAL NUMBER OF PAGES: The total page count should follow normal pagination procedures, $i . e .$, enter the number of pages containing information

7b. NUMBER OF REFERENCES: Enter the total number of references cited in the report.

8a. CONTRACT OR GRANT NUMBER: If appropriate, enter the applicable number of the contract or grant under which the report was written.

$8 b, 8 c, \& 8 d$. PROJECT NUMBER: Enter the appropriate military department identification, such as project number, subproject number, system numbers, task number, etc.

9a. ORIGINATOR'S REPORT NUMBER(S): Enter the official report number by which the document will be identified and controlled by the originating activity. This number must be unique to this report.

9b. OTHER REPORT NUMBER(\$): If the report has been assigned any other report numbers (either by the originator or by the sponsor), also enter this number(s).

10. AVALABILITY/LIMITATION NOTICES: Enter any $1 \mathrm{im}$ itations on further dissemination of the report, other than those imposed by security classification, using standard statements such as:

(1) "Qualified requesters may obtain copies of this report from DDC"

(2) "Foreign announcement and dissemination of this report by DDC is not authorized."

(3) "U. S. Government agencies may obtain copies of this report directly from DDC. Other qual ified DDC users shall request through

(4) "U. S. military agencies may obtain copies of this report directly from DDC. Other qualified users shall request through

(5) "All distribution of this report is controlled. Qualified DDC users shall request through

If the report has been furnished to the Office of Technical Services, Department of Commerce, for sale to the public, indi cate this fact and enter the price, if known.

11. SUPPLEMENTARY NOTES: Use for additional explanatory notes.

12. SPONSORING MILITARY ACTIVITY: Enter the name of the departmental project office or laboratory sponsoring (pay ing for) the research and development. Include address.

13. ABSTRACT: Enter an abstract giving a brief and factual summary of the document indicative of the report, even though it may also appear elsewhere in the body of the technical report. If additional space is required, a continuation sheet sha be attached.

It is highly desirable that the abstract of classified repor be unclassified. Each paragraph of the abstract shall end witl an indication of the military sacurity classification of the information in the paragraph, represented as $(T S)$. (S), (C), or (U

There is no limitation on the length of the abstract. How ever, the suggested length is from 150 to 225 words.

14. KEY WORDS: Key words are technically meaningful term or short phrases that characterize a report and may be used as index entries for cataloging the report. Key words must be selected so that no security classification is required. Identi fiers, such as equipment model designation, trade name, milite project code name, geographic location, may be used as key words but will be followed by an indication of technical context. The assignment of links, rales, and weights is optional. 


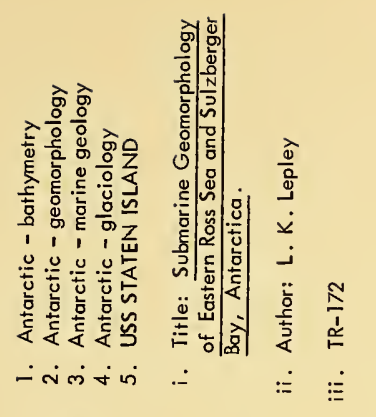

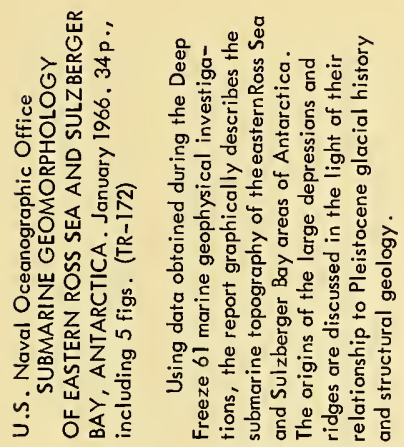
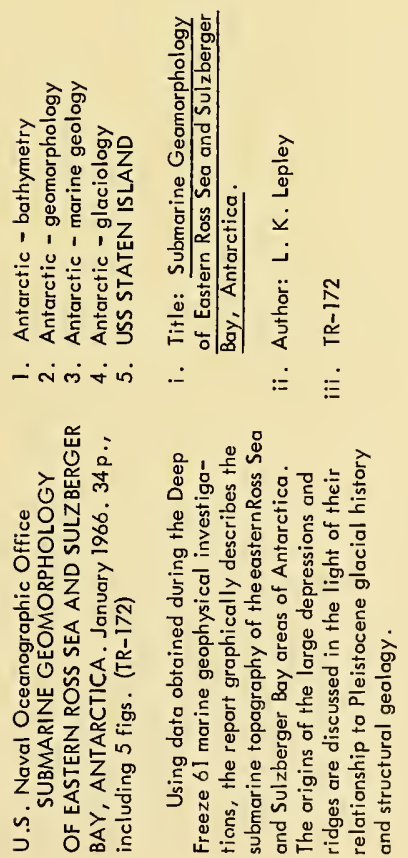
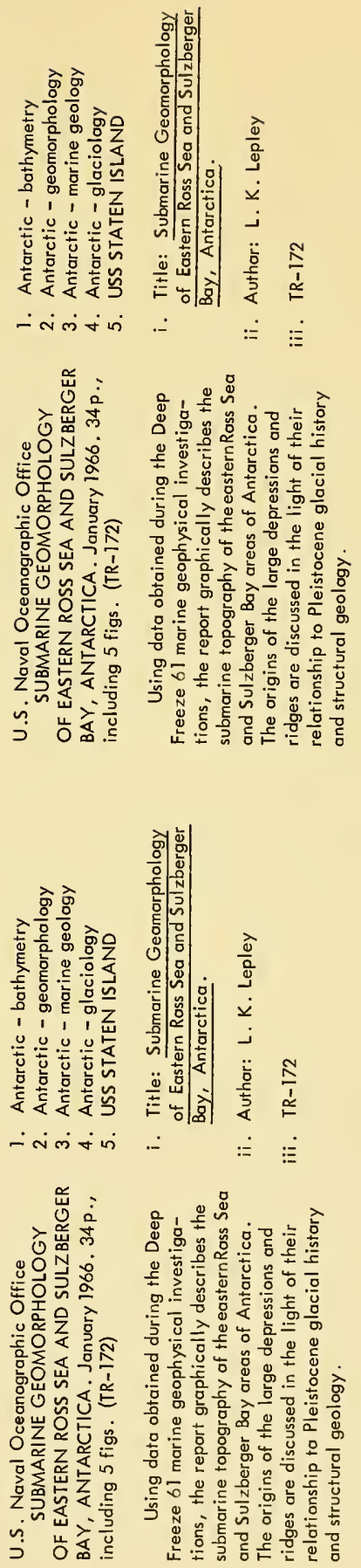


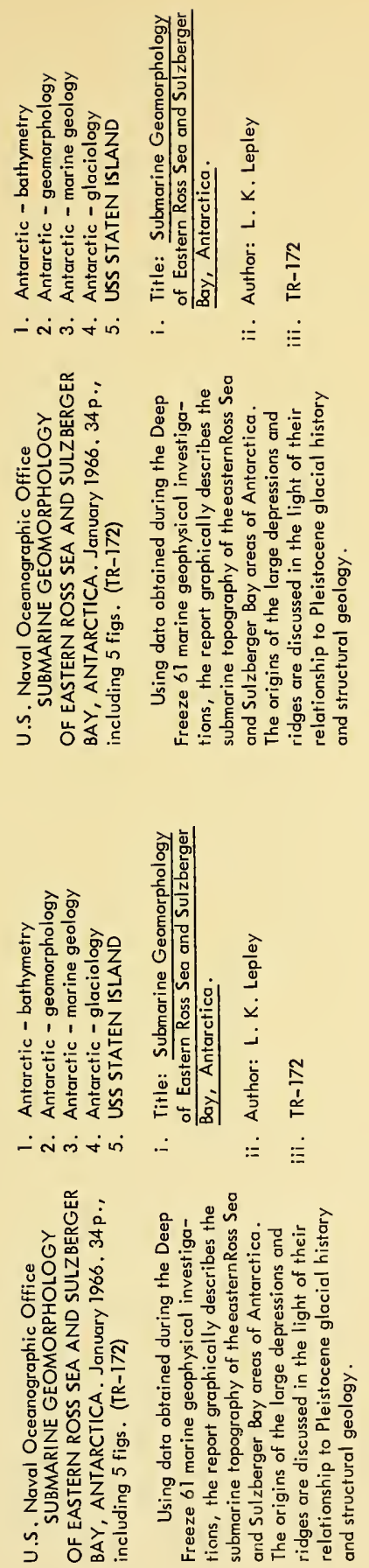
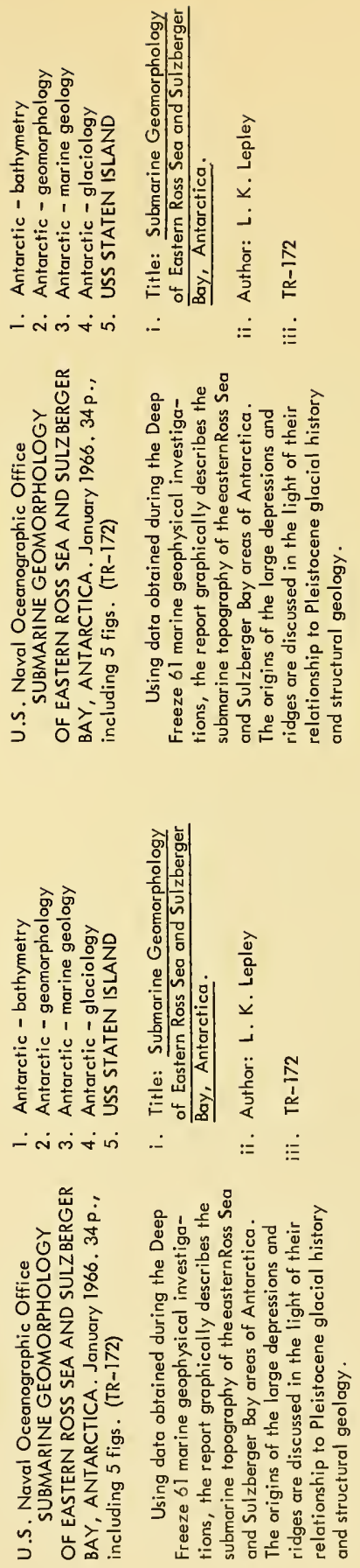

